University of Nebraska - Lincoln

DigitalCommons@University of Nebraska - Lincoln

Agronomy \& Horticulture -- Faculty Publications

Agronomy and Horticulture Department

7-1945

\title{
A Seven-Year Quantitative Study of Succession in Grassland
}

J. E. Weaver

University of Nebraska-Lincoln

W. E. Bruner

Follow this and additional works at: https://digitalcommons.unl.edu/agronomyfacpub

Part of the Plant Sciences Commons

Weaver, J. E. and Bruner, W. E., "A Seven-Year Quantitative Study of Succession in Grassland" (1945). Agronomy \& Horticulture -- Faculty Publications. 474.

https://digitalcommons.unl.edu/agronomyfacpub/474

This Article is brought to you for free and open access by the Agronomy and Horticulture Department at DigitalCommons@University of Nebraska - Lincoln. It has been accepted for inclusion in Agronomy \& Horticulture -Faculty Publications by an authorized administrator of DigitalCommons@University of Nebraska - Lincoln. 


\title{
A SEVEN-YEAR QUAN'TITATIVE STUDY OF SUCCESSION IN GRASSLAND ${ }^{1}$
}

\author{
J. E. Weaver \\ University of Nebraska \\ and \\ W. E. BrUNER \\ State Teachers College \\ Kearney, Nebraska
}

${ }^{1}$ Contribution No. 144 from the Department of Botany, University of Nebraska. This study was aided by a grant from the Iniversity Research Council, University of Nebraska. 


\section{TABLE OF CONTENTS}

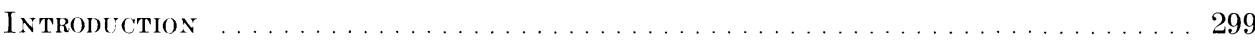

Location of Area and Description of Vegetation .................299

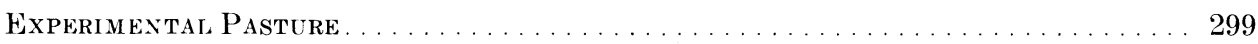

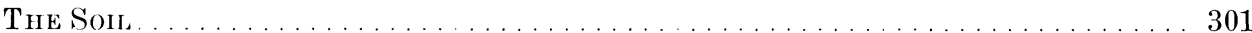

Methods of Studying Vegetation and Environment ............... 301

Precipitation and Water Content of Soll..................... 301

Succession as Measured by Number and Distribution of Stems........... 303

Succession in Quadrats Dominated by Sand Dropseed ................ 303

Succession in Quadrats Dominated by Little Bluestem . . . . . . . . . . . . 304

Succession in Quadrats Dominated by Kentucky Bluegrass............... 306

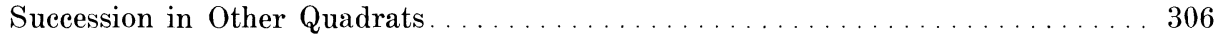

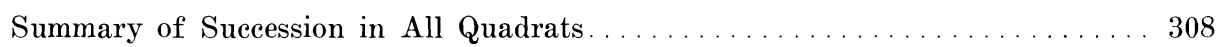

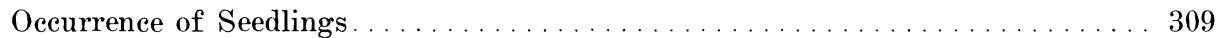

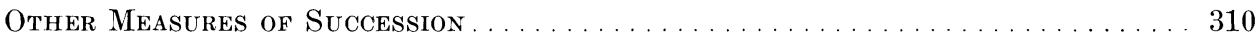

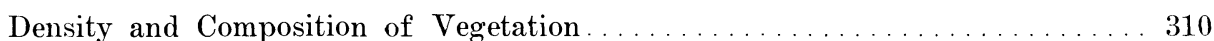

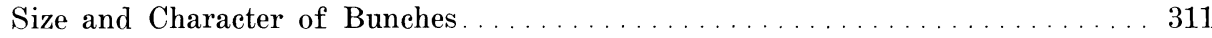

Increase in Vigor of Vegetation in Relation to Period of Succession . . . . . . . . . 311

Succession as Measured by Yield . . . . . . . . . . . . . . . . . 312

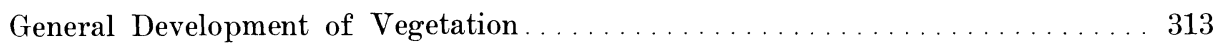

Plant Cover in $1938 \ldots \ldots \ldots \ldots \ldots \ldots \ldots \ldots \ldots \ldots \ldots \ldots$

Plant Cover in $1940 \ldots \ldots \ldots \ldots \ldots \ldots \ldots \ldots \ldots \ldots \ldots \ldots$

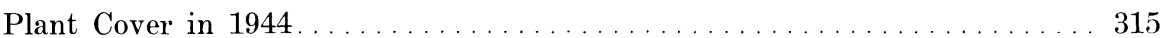

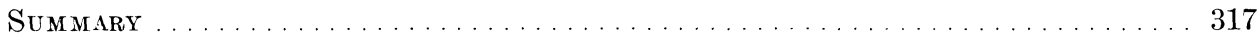

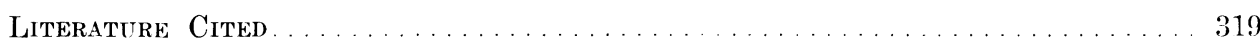




\section{A SEVEN-YEAR QUANTITATIVE STUDY OF SUCCESSION IN GRASSLAND}

\section{INTRODUCTION}

The study of plant succession has contributed more than any other single line of investigation to a deeper insight into the nature of vegetation. Earlier studies of succession, especially in grassland, were largely those of the primary sere. But with the utilization of the prairies for grazing, and the abandonment of submarginal land after a short period of cropping, numerous investigations of secondary successions were made. The earlier studies have been discussed by Clements (1916) in "Plant Succession." Sampson's plant succession in relation to range management appeared in 1919. Many of the more recent investigations of subseres in grassland and on abandoned lands have been reviewed by Drew (1942). Costello (1944) has studied the grassland subsere in northeastern Colorado. Weaver and Albertson (1944) have traced the subsere following the recent great drought over a vast central area of both true and mixed prairie. Information on the rate and nature of natural revegetation of depleted ranges and abandoned cultivated land is of basic importance to many problems of soil conservation and land use.

The present study was begun in 1937 to determine the course of succession in an old native pasture under complete protection from grazing. The nature and rate of regeneration of the vegetation in its return toward the grassland climax have been ascertained and changes in the plant population fully recorded.

\section{LOCATION OF AREA AND DESCRIPTION OF VEGETATION}

The area selected lies 3 miles north and 1 mile west of the University of Nebraska in Lincoln. It consists of a large tract of unbroken native prairie, a considerable portion of which was fenced and grazed continuously for 23 years. The prairie and pasture cover gently rolling to moderately hilly land. They are about one half mile long, from north to south, and about one quarter mile wide. The soil is Carrington clay loam, a type common and extensive in eastern Nebraska, as is also this type of topography.

The prairie vegetation from which the pasture originated is of the upland mid-grass type. The chief dominant is little bluestem (Andropogon scoparius), 2 which alone constitutes about 60 percent of the cover. Needle grass (Stipa spartea), prairie dropseed (Sporobolus heterolepis), June grass (Koeleria cristata), and side-oats grama (Bouteloua curtipendula) are all important species. The sod-forming big bluestem (Andropogon furcatus), with a very little Indian grass (Sorghastrum nutans), is dominant in the ravine's, but has also spread throughout much of the upland where, like Kentucky bluegrass (Poa pratensis), it forms a 3 to 10 percent mixture almost

2 'The nomenclature of grasses follows Hitchcock's Manual of the Grasses of the United States; that of other plants Britton and Brown's Illustrated Flora. throughout. Scribner's panic grass (Panicum scribnerianum) and Wilcox's panic grass (P. wilcoxianum) are low-growing, interstitial species of very common occurrence. Carex pennsylvanica is the chief sedge. In addition to the grasses and sedges there are numerous composites, legumes, and other forbs.

The grasses normally reach a general level of 12 to 18 inches in July when vegetative growth is nearly complete. The basal cover is about 13 percent and the foliage cover varies between 75 and 100 percent during a season of approximately normal precipitation. The soil is almost entirely concealed by debris, usually only a few millimeters thick. This prairie had not been grazed for at least 40 years, and probably only moderately since the disappearance of the bison. It is used for the production of hay and is mowed annually in late summer or fall, except in years of extreme drought. But the great drought of 1934-36 had a very destructive effect on grassland. In the prairie this resulted in marked changes in the normal composition of the vegetation (Weaver and Albertson, 1936). Chief among these was the high mortality of little bluestem, many bunches being entirely killed and others represented by a mere fringe of dwarfed stems. June grass, needle grass, and bluegrass also suffered greatly. Losses were severe among grasses of the understory, notably Panicum scribnerianum and $P$. wilcoxianum, as they were also among forbs (such as Antennaria campestris and Viola pedatifida) of similar dependence upon the mid grasses for protection from too great insolation and too low humidity. Big bluestem and deeply rooted forbs were not greatly affected.

The excellent conditions for growth in spring and early summer following the drought of 1934 resulted in vigorous development of the survivors, rapid reseeding, and invasion of the bared areas by rhizomes. Hence much of the area formerly occupied by little bluestem was taken over by June grass and needle grass. Prairie dropseed became much more abundant, as did also side-oats grama. Even bluegrass spread rapidly from the scattered, well shaded areas where it had not succumbed to drought.

\section{EXPERIMENTAL PASTURE}

The experimental pasture adjoining the prairie had apparently never been greatly overgrazed. In 1932-33 it was studied and described as belonging to the No. 3 type, which is characterized by about half dominance of bluestems and other prairie grasses and half of bluegrass (Weaver and Hansen, 1941). The cover was practically intact, annual weedy species were few, and only a modicum of the usual perennial pasture weeds occurred. Two pasture areas adjoining the prairie were exclosed to stock, a smaller one of 24 square rods on a west hillside near the south end of the pasture and a larger one, 4.5 rods wide and 31 rods long, extending from the top of a low 
hill northward to and including its level base. The slope in the main area varied from 1 to 5 percent (Fig. 1). The south exclosure was typical of the more hilly portion of the pasture. It included a west-facing, gentle slope and also a portion of a northeast one. These were separated by a small ravine.

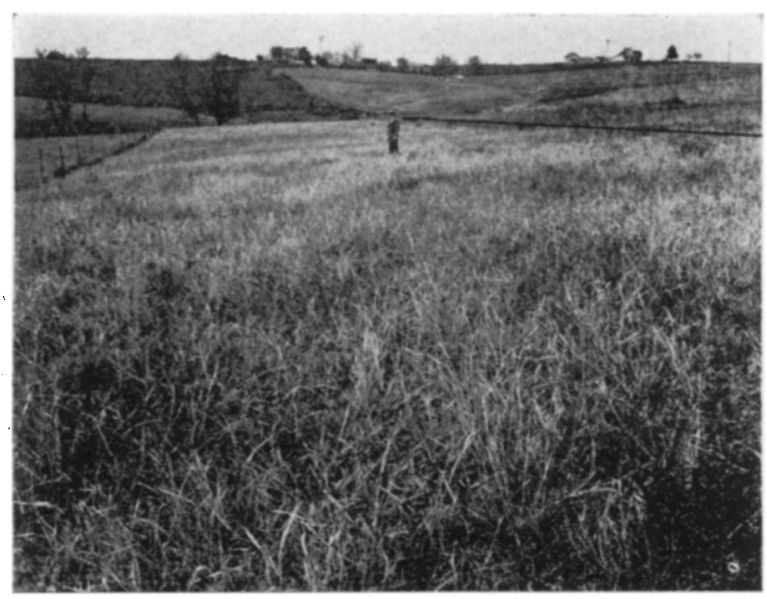

Fig. 1. A part of the experimental pasture in March, 1938, after one year of succession. Sand dropseed (Sporobolus cryptandrus) gives tone to the landscape. Climax prairie occurs to the right (east) of the black line.

The chief changes in pasture resulting from the drought were the almost complete disappearance of bluegrass and great injury to little bluestem. Sand dropseed (Sporobolus cryptandrus) increased greatly (Weaver and Hansen, 1939). There was a great increase in side-oats grama, and an increase in annual weeds.

The chief characteristic of the vegetation in the south exclosure in the spring of 1937 was the scarcity of nearly all prairie grasses; they were found only upon close observation. The bluestems, for example, sometimes occurred at the rate of only 1 to 4 stems or small tufts per square meter; often there were none. There were, as in the prairie, many areas of a few square inches to several square feet almost completely unoccupied by vegetation. Dense patches of the annual peppergrass (Lepidium densiflorum) occurred throughout much of the pasture. Spikes of Pursh's plantain (Plantago purshii) were so numerous locally as to give a distinetly gray color. An abundance of the bright green-colored horseweed (Leptilon canadense) was confined to the ravine or to nearly bare ground. No other weeds were of unusual importance. A two thirds stand of bluegrass intermixed with scattered stalks of thrifty big bluestem grew in a narrow strip in and bordering the ravine. Scattered bunches of June grass and a few relict prairie forbs were found. In bare or half-bare soil, plants of sand dropseed grew sparingly.

The southern or upland half of the large north exclosure was characterized by the almost complete disappearance of all the prairie grasses except thinly scattered bunches of June grass and side-oats grama.
An exception was the occurrence of about a dozen small patches. of blue grama (Bouteloua gracilis) which were well defined but in general depleted to only one third or less of the normal basal area. Bluegrass occurred in patches ranging from a few square inches to a square yard in area. There was much nearly unoccupied ground in which sand dropseed was the only grass. Large patches of smooth goldenrod (Solidago glaberrima), smaller but more frequent ones of many-flowered aster (Aster multiflorus), and scattered plants or aggregations of Pursh's plantain were the chief weeds. Yarrow (Achillea occidentalis) and horseweed were scattered throughout, and in the lower part an infestation of peppergrass occurred.

The outstanding feature of the northern (lower) half of the exclosure was the almost continuous stand of peppergrass, the crowns overlapping almost everywhere. Before the drought this area was clothed with a nearly continuous sod of bluegrass, of which only a few scattered patches remained (Fig. 2). Other prairie grasses were rarely found, and peppergrass thrived. Sand dropseed usually occurred under this weed, though some bared areas produced only weeds. In the thinner stands, sand dropseed numbered only three or four plants per square meter, but in the thickest ones it covered one fourth to one third of the soil. Yarrow was common in small patches, and the annual horseweed was scattered thickly.
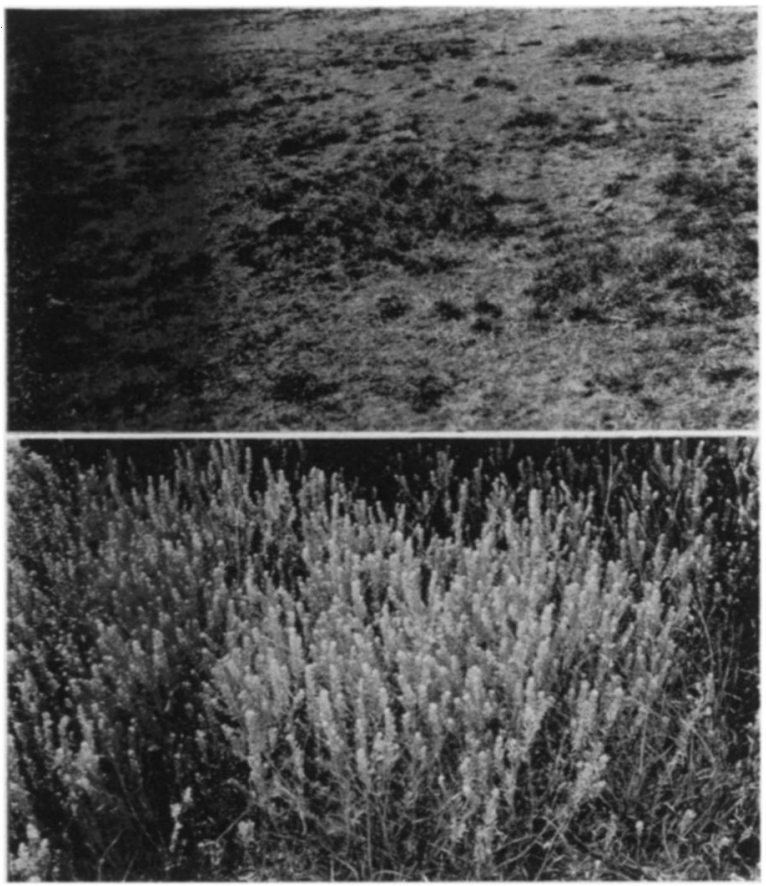

Fra. 2. (Upper) Relict bunches and patches (dark) of Kentucky bluegrass (Poa pratensis) on the lower ground in the north pasture in early spring of 1936. Further losses were sustained during the dry summer. (Lower) Dense stand of peppergrass (Lepidium densiflorum), a weed which was extremely abundant following the early years of drought. Average height is 14 inches. June 7,1937 . 


\section{THE SOIL}

The soil has a mature profile. The A horizon is rark in color, fairly rich in humus, and extends to a depth of 18 inches. Mechanical analysis showed that it contained about 25 percent very fine sand, 38 percent silt, and 26 percent clay, ${ }^{3}$ the remainder consisting of larger sand particles. At 12 inches depth the soil becomes lighter in color, and the clay loam of the surface foot grades into clay. The B horizon extends about 18 inches deeper. It consists of a yellowish clay which is plastic when wet but very hard when dry. The prismatic structure is well developed and during drought a great shrinkage occurs among the vertical prisms. The $\mathrm{C}$ horizon begins at about 32 to 36 inches depth, depending upon slope. While there is an entire absence of coarse sand to this depth, the sand component consisting almost wholly of very fine sand, in the $\mathrm{C}$ horizon the clay gradually becomes intermixed with an increasing proportion of coarser sand. There is no lime laver at any depth; water percolates freely through the massive layer of parent material. Hygroscopic coefficients and $\mathrm{pH}$ values are given in Table 1.

TABLE 1. Hygroscopic coefficients of soil and subsoil and $\mathrm{HH}$ values to a depth of 6 feet in prairie and pasture.

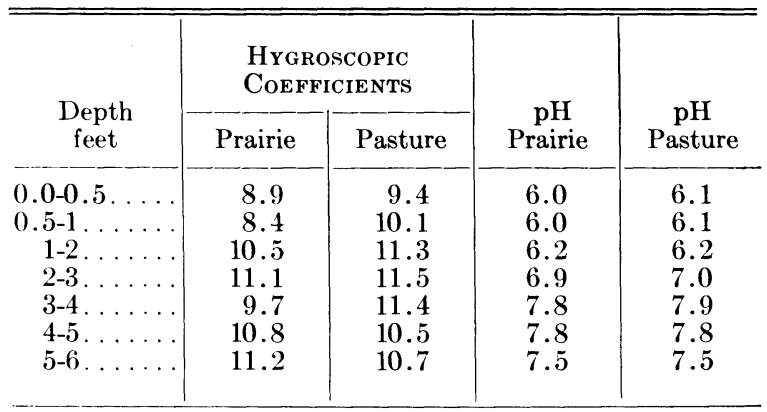

\section{METHODS OF STUDYING VEGETATION AND} ENVIRONMENT

Permanent meter quadrats were established in the exclosures early in 1937 for the purpose of determining quantitatively the increase or decrease of various species during a period of 7 years. Because of the variety and nature of the vegetation, the list $01^{\circ}$ census method was employed. Ten permanent quadrats were marked out at random in widely distributed areas where sand dropseed dominated. Another lot of 10 was located at random in local areas revealing remnants of the bluestems, since over many square meters none were found. Ten other quadrats were located on the lower ground where small relict patches of bluegrass persisted. Ten quadrats, each of which included patches of blue grama, were also established. Some of these patches were old stands; others had been formed from seedlings after the drought began. Three quadrats were selected as representative of bared areas occupied by peppergrass. Stem counts of all plants occurring in these 43 quadrats were made annually in June and July. An ex-

3 Clay includes all particles with diameters less than $0.005 \mathrm{~mm}$. ception was the dense patches of blue grama where the percentage of basal area, an inch from the soil surface, was ascertained.

In addition to detailed examination of the vegetation each month during the growing season, quadrats were used in ascertaining the density of the foliage cover, basal area, and percentage composition. Clip quadrats were extensively employed near the end of the dry cycle in 1940, and after two years of good precipitation (1943) to ascertain the amount and composition of the vegetation produced after different numbers of years of succession. Subseres of shorter duration resulted from exclosing to cattle new portions of the original pasture in 1939 and 1940 with those exclosed in 1937. These were of great value in comparing earlier stages of the succession with later ones. Data obtained during the earlier years (1937-40) have also been used in a study of regeneration of native midwestern pastures (Weaver and Hansen 1941a).

Since precipitation and water content of soil are the principal factors controlling the development of vegetation in this central prairie area, chief attention was centered on the water relations. Data on temperature, humidity, and evaporation were obtained, but they are not presented. Precipitation during the early years of the study was measured by means of a standard rain gauge placed in the area, but data from the Weather Bureau station at Lincoln were used thereafter. Samples of soil for water content determinations were usually taken weekly to 4 feet and on alternate weeks to 6 feet in depth. Briggs' geotomes were employed. Samples were obtained in foot sections, except that the first and second 6 -inch soil cores were taken separately. The hygroscopic coefficient of the soil at each depth was subtracted from the total water content, thus giving the approximate amount of water available for plant growth.

\section{PRECIPITATION AND WATER CONTENT OF SOIL}

The year 1937 was one of deficient precipitation, low humidity, and abnormally high temperatures. So severe had been the preceding drought that late in April only the surface two feet of soil had a good water content. Rainfall in April (1.2 in.) and May (1.9) was 1.3 and 2.2 inches, respectively, below normal. Rainfall in June (3.8 in.), July (3.1), August (1.7), and September (1.1), was in order, 0.5, 0.8, 1.9, and 1.9 inches below normal. Examination of Figure 3 shows that water for growth was not available to the vegetation except at irregular intervals in the surface foot of soil, and that after June less that 2 percent was available in the second foot.

The year 1938 was much more favorable to plant development. Rainfall in April was more than an inch above normal, and that of May 1.6 inches in excess of normal precipitation. The very favorable water relations of the soil in spring and early summer are shown in Figure 3. Vegetation flourished, but growth was later retarded by a deficiency of soil moisture. Rainfall in both June and July was about 


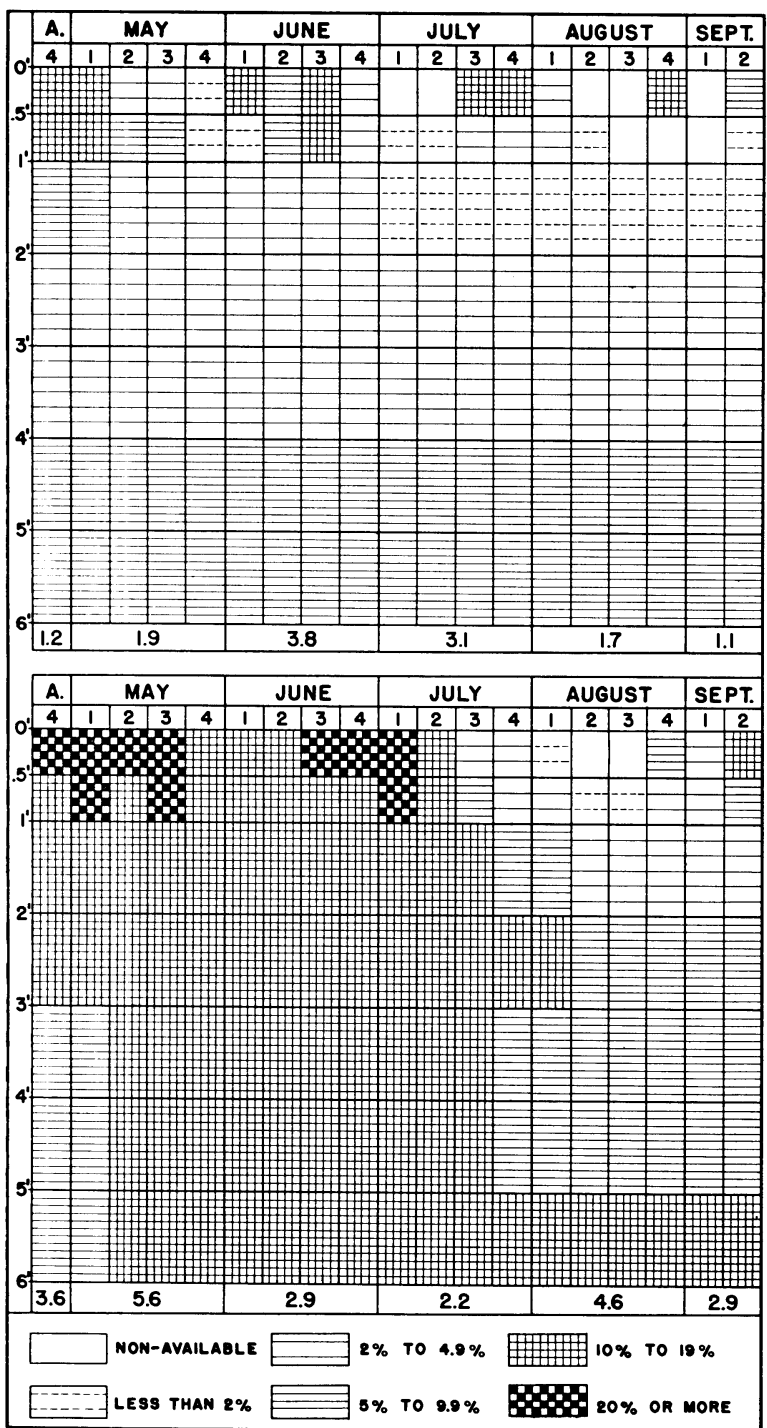

FIG. 3. Available soil moisture to a depth of 6 feet at Lincoln, Nebr., during 1937 (upper) and 1938 (lower). Mean annual precipitation is 27.9 inches. Numbers at the top of the columns indicate the first, second, ete., week of sampling; those at the base are total current monthly rainfall.

1.5 inches below normal, and this resulted in midsummer drought. The 2 years' growth of grasses without trampling and the winter's freezing and thawing, however, had increased the rate of water infiltration into the soil. 4

The entire grazing season of 1939, except for June, was one of deficient rainfall (Fig. 4). A small moisture deficiency in April became acute in May when the rainfall was 2.5 inches below normal. The normal June precipitation (4.3 in.) caused the vegetation to flourish. Subnormal rainfall in July, amounting to more than an inch below the mean, retarded growth. Precipitation during August was nearly an

4 Vegetation was removed from the experimental areas each year; it was usually mowed, raked. and hauled away in early inch below normal. Soil moisture was reduced to the nonavailable point in the surface 6 inches several times, and available water content of the soil to a depth of 2 feet was rather continuously less than 2 percent after June 30. This deficiency resulted in the rapid drying of the vegetation.

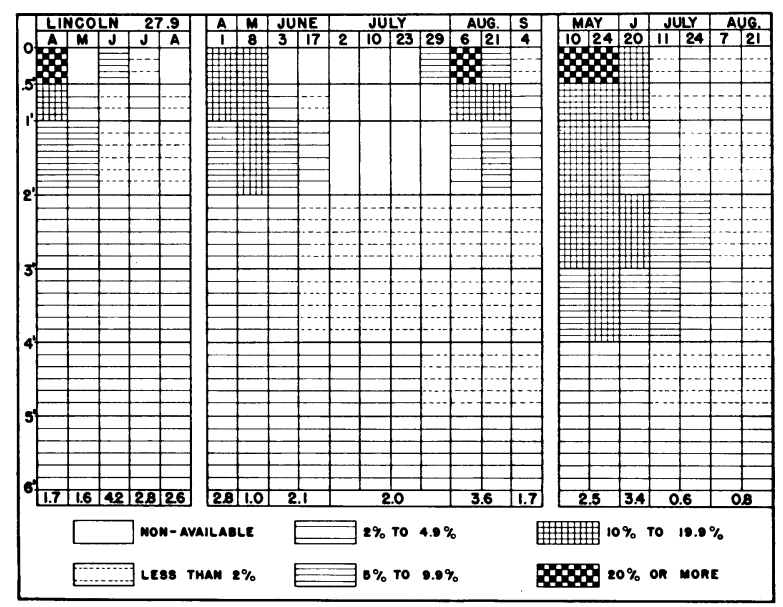

Fig. 4. Available soil moisture to a depth of 6 feet at Lincoln, Nebr., during 1939 (left panel), 1940 (center), and 1941 (right panel). Numbers at the top of the columns are dates of sampling; those at the base are total current monthly rainfall.

The spring of 1940 was cool and late; April rainfall was slightly above normal, and there was sufficient water content to promote good growth. Rainfall in May was only 1 inch (3.1 inches below normal), and only about half the normal precipitation fell in June (2.1 in.). Despite these conditions, the grasses made good growth, because of favorable distribution of rainfall, until late in June. Since no more rain fell until almost the end of July, there was a period of four weeks during which growth ceased. Available water content was nearly exhausted to 4 or 5 feet and the grasses dried (Fig. 4). Some were bleached nearly white; the bluestems took on the reddish-brown colors of autumn. But growth was renewed late in July, and continued throughout August under a normal rainfall.

The growing season of 1941 was characterized by a late spring, a wet April, rather light rainfall in May and June, and severe drought during July and August (Fig. 4). Rainfall in May and June was 1.6 and 0.9 inches, respectively, below normal. Of the normal rainfall for July (3.9 in.) and August (3.5 in.), only 0.6 and 0.8 in., respectively, fell during these months. Conditions of growth were good until the last week in June, when a severe midsummer drought of long duration began. The vegetation became discolored and dry and growth ceased. Vegetation regained its green color after rains late in August. Only a few of the most drought resistant grasses, as sand dropseed, side-oats grama, and blue grama, produced a small crop of flower stalks in the most favorable places.

In 1942 rainfall was especially heavy during April, May, and June, and with few exceptions a good water 
content of soil was maintained at most soil depths throughout the season (Fig. 5). The drought had been definitely broken and the plant cover became much taller and denser.
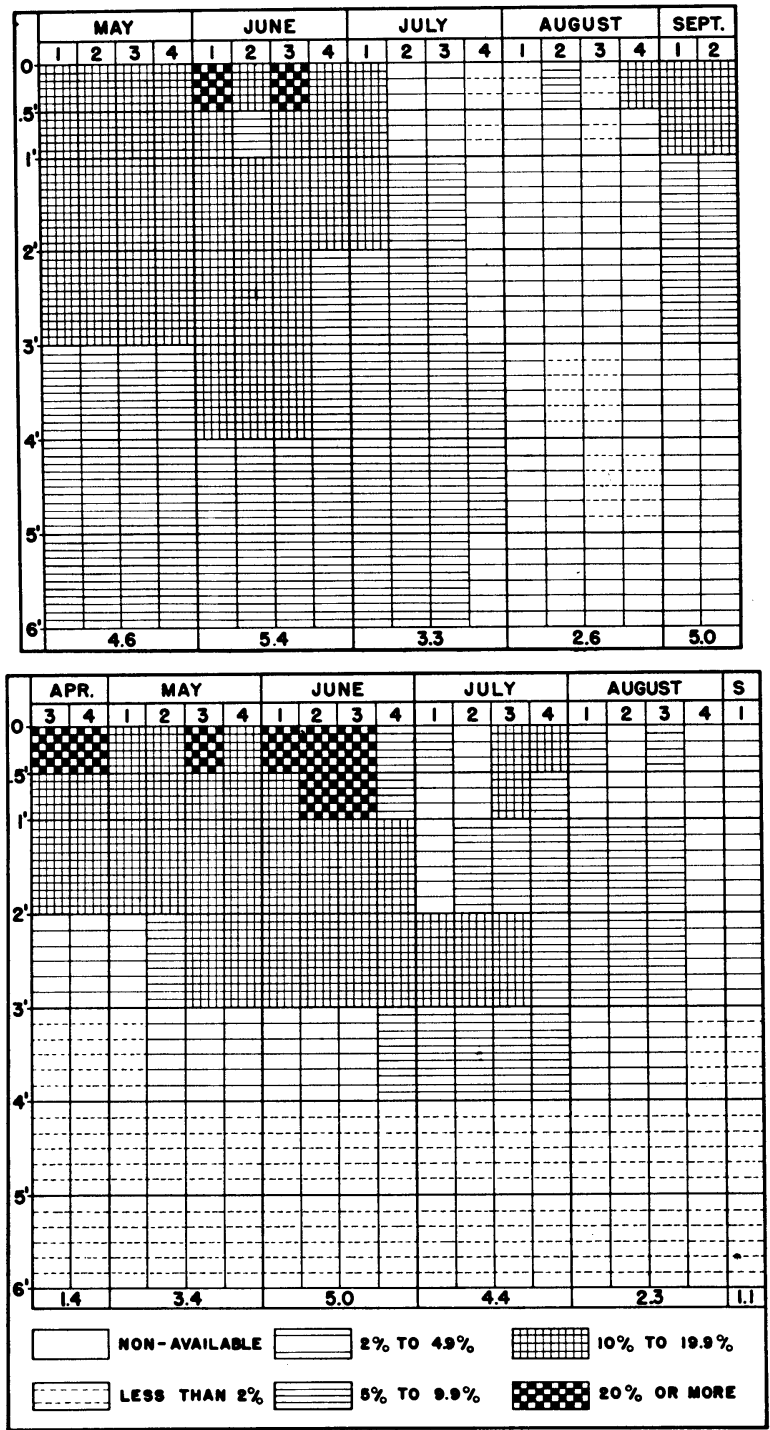

Fig. 5. Available soil moisture to a depth of 6 feet at Lincoln, Nebr., during 1942 (upper) and 1943 (lower). Numbers at the top of the columns indicate first, second, ete., week of sampling; those at the base are total current monthly rainfall.

Although the total precipitation in 1943 was somewhat less than that of either of the two preceding years, this deficiency occurred mainly late in the year after the grasses had made good growth. In 1942 the subsoil had "received much moisture, and this reserve supply was available for growth in 1943, although there was little available water below a depth of 4 feet (Fig. 5). Vegetation had greatly recovered from drought, and both density of cover and yields were high.

The water relations, which were overwhelmingly the controlling factor in the growth of vegetation and community development, may be summarized for ready reference in interpreting the progress of succession.

1937 A dry year (19.4 inches of the normal 27.9 inches precipitation) following very severe drought. Vegetation at very low ebb.

1938 Above normal precipitation (28.4 in.) and an excellent year for growth, except for moderate midsummer drought. Good recovery toward former prairie conditions.

1939 Deficient rainfall (19.7 in.) except in June, especially after midsummer when growth ceased.

1940 Precipitation low (23.2 in.). Spring and early summer favorable to good growth; severe midsummer drought, growth renewed in August.

1941 Precipitation nearly normal (26.1 in.). Abundant soil moisture until July, then severe summer drought.

1942 Above normal precipitation (28.8 in.). Good moisture reserves in spring; excellent growth.

1943 Low rainfall (21.8 in.) but excellent summer for growth. Accumulated moisture reserves promoted good yields despite occasional deficient rainfall.

\section{SUCCESSION AS MEASURED BY NUMBER AND DISTRIBUTION OF STEMS}

Succession in each group of quadrats was traced year by year. Quadrats dominated by Kentucky bluegrass were listed finally in the summer of 1941, but those in which sand dropseed or little bluestem dominated were listed annually, including 1943.

\section{Succession in Quadrats Dominated BY SAND DRopseed}

Changes in plant population in 10 quadrats dominated by Sporobolus cryptandrus are shown for each of the 7 years in Table 2. At first sand dropseed constituted 80 percent of the entire vegetation, exclusive of native forbs and ruderals. There was a steady increase of the dominant each year-17, 22, and 35 percent over that of the preceding yearuntil 1941. That year marked a decrease as did also 1942 and 1943 (Table 2 and Fig. 6). Thus, in 1940 it composed 68 percent of all the grasses as measured by number of stems, but in 1943 only 35 percent. Despite the decrease in number of stems, the plants were most widely distributed in 1943 when they occurred in 814 of the $1,000 \mathrm{sq}$. dm. units as against 762 in 1937, and 510 in 1940 when the number of stems was largest (Fig. 6).

Bouteloua curtipendula, the second most abundant grass, increased steadily until 1940. It then showed a temporary but slight decrease, but reached a maximum of 16 percent of the total grass cover in 1942 . It decreased sharply in 1943. Bouteloua hirsuta decreased with the thickening of the cover after 1940, but Poa pratensis increased with the return of greater precipitation. Relict bunches of Andropogon scoparius gained in number of stems especially after 1940, and A. furcatus also increased, partly by the spread of rhizomes. Both species increased their stem output by more than 900 percent. But even 
TABLE 2. Species of grasses and sedges, native forbs, and ruderals in 10 meter quadrats dominated by Sporobolus cryptandrus, and changes in plant populations during each year of succession.

\begin{tabular}{|c|c|c|c|c|c|c|c|c|}
\hline \multirow{2}{*}{ Species } & \multicolumn{7}{|c|}{ Number of Stems } & \multirow{2}{*}{ 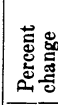 } \\
\hline & 1937 & 1938 & 1939 & 1940 & 1941 & 1942 & 1943 & \\
\hline Sporobolus cryptandrus & 6,285 & 7,356 & 8,998 & 12,161 & 10,507 & 6,870 & 6,127 & -3 \\
\hline Bouteloua curtipendula & 448 & 954 & 1,992 & 1,849 & 1,796 & 2,292 & 1,387 & 210 \\
\hline Bouteloua hirsuta.... & 365 & 717 & 895 & 774 & 535 & 313 & 222 & -39 \\
\hline Poa pratensis....... & 315 & 82 & 96 & 96 & 375 & 380 & 960 & 205 \\
\hline Andropogon furcatus. . & 181 & 415 & 1,006 & 1,210 & 1,070 & 1,160 & 1,814 & 902 \\
\hline Andropogon scoparius. & 112 & 175 & 524 & 732 & 1,405 & 1,247 & 1,182 & 955 \\
\hline The 10 other species. . & 134 & 903 & 932 & 1,163 & 1,183 & 2,342 & 5,626 & 4,099 \\
\hline Total. & 7,840 & 10,602 & 14,443 & 17,985 & 16,871 & 14,604 & 17,318 & 121 \\
\hline Native Forbs & & & & & & & & \\
\hline Plantago purshii. . & 796 & 576 & 291 & 55 & 55 & 30 & & -100 \\
\hline Hedeoma hispida... & 586 & 651 & 136 & 13 & 15 & 70 & & -100 \\
\hline Solidago glaberrima. & 90 & 170 & 426 & 215 & 315 & 192 & 922 & 924 \\
\hline Aster multiflorus.... & 29 & 100 & 132 & 194 & 284 & 244 & 284 & 879 \\
\hline The 15 other forbs... & 134 & 148 & 138 & 70 & 327 & 282 & 880 & 557 \\
\hline Total.. & 1,635 & 1,645 & 1,123 & 547 & 996 & 818 & 2,086 & 28 \\
\hline RUderals & & & & & & & & \\
\hline Lepidium densiflorum. & 1,785 & 5 & 0 & 24 & 38 & 2 & & -100 \\
\hline Leptilon canadense.... & 1,200 & 57 & 28 & 7 & 13 & 474 & 2,287 & 91 \\
\hline Hordeum pusillum.... & 323 & 1,680 & 940 & 873 & 824 & 4,848 & 10,154 & 3,044 \\
\hline The 9 other ruderals & 62 & 88 & 29 & 32 & 37 & 26 & 338 & 445 \\
\hline Total. & 3,370 & 1,830 & 997 & 936 & 912 & 5,350 & 12,779 & 279 \\
\hline
\end{tabular}

in $1943 \mathrm{~A}$. scoparius occurred in only 81 and $A$. furcatus in 224 of the $1,000 \mathrm{sq}$. $\mathrm{dm}$. This indicated a distinct loss after the 1940 drought. The greatest increases were made by the group of "other species." At first they composed less than 2 percent of the grass population. They then maintained about 8 percent until 1941, but by 1942 they ranked next to Sporobolus in number of stems. These 10 species occurred in only $43 \mathrm{sq}$. $\mathrm{dm}$. in 1937 , but in 470 in 1943.

The chief changes in the quadrats during the seven years of succession were a great increase in sand dropseed until the end of the drought in 1941, and a gradual decrease in both number and size of stems as the more mesic grasses regained their vigor. The 10 other grasses and sedges occur in lists of total plant population in Table 3 .

Only 19 native forbs were found in 1937. Plantago purshii was most abundant. It decreased yearly and disappeared in 1943. Hedeoma hispida likewise decreased greatly during 1939 and later disappeared. But Solidago glaberrima and Aster multiflorus increased in these quadrats. As a group, however, the native forbs decreased 67 percent by 1940 . They became much more plentiful with the return of abundant soil moisture, as was common in prairie elsewhere.

Of the ruderals, Lepidium densiflorum and Leptilon canadense, both annuals, were extremely abundant in 1937. The first almost disappeared thereafter, but Leptilon was again extremely abundant in 1.943 . This phenomenon was widespread. The amount of Hordeum pusillum was greatest in years of good
TABLE 3. List of species found in the 43 quadrats; the more abundant species are placed at or near the top of each list.

\begin{tabular}{|c|c|c|}
\hline Grasses and Sedges & Native Forbs (continued) & Ruderals \\
\hline $\begin{array}{l}\text { Sporobolus cryptandrus } \\
\text { Sand dropseed }\end{array}$ & $\begin{array}{l}\text { Aster multiflorus } \\
\text { Many-flowered aster }\end{array}$ & $\begin{array}{l}\text { Lepidium densiflorum } \\
\text { Peppergrass }\end{array}$ \\
\hline $\begin{array}{l}\text { Bouteloua curtipendula } \\
\text { Side-oats grama }\end{array}$ & $\begin{array}{l}\text { Xanthoxalis stricta } \\
\text { Yellow wood sorrel }\end{array}$ & $\begin{array}{l}\text { Leptilon canadense } \\
\text { Horseweed }\end{array}$ \\
\hline $\begin{array}{l}\text { Poa pratensis } \\
\text { Kentucky bluegrass }\end{array}$ & $\begin{array}{l}\text { Senecio plattensis } \\
\text { Ragwort }\end{array}$ & $\begin{array}{l}\text { Hordeum pusillum } \\
\text { Little barley }\end{array}$ \\
\hline $\begin{array}{l}\text { Andropogon furcatus } \\
\text { Big bluestem }\end{array}$ & $\begin{array}{l}\text { Lithospermum linearifolium } \\
\text { Narrow-leaved puccoon }\end{array}$ & $\begin{array}{l}\text { Grindelia squarrosa } \\
\text { Gumweed }\end{array}$ \\
\hline $\begin{array}{l}\text { Andropogon scoparius } \\
\text { Little bluestem }\end{array}$ & $\begin{array}{l}\text { Artemisia gnaphalodes } \\
\text { Prairie sage }\end{array}$ & $\begin{array}{l}\text { Bromus tectorum } \\
\text { Downy chess }\end{array}$ \\
\hline $\begin{array}{l}\text { Koeleria cristata } \\
\text { June grass }\end{array}$ & $\begin{array}{l}\text { Antennaria campestris } \\
\text { Prairie cat's-foot }\end{array}$ & $\begin{array}{l}\text { Schedonnardus paniculatus } \\
\text { Tumblegrass }\end{array}$ \\
\hline $\begin{array}{l}\text { Carex pennsylvanica } \\
\text { Pennsylvania sedge }\end{array}$ & $\begin{array}{l}\text { Cathartolinum sulcatum } \\
\text { Grooved yellow flax }\end{array}$ & $\begin{array}{l}\text { Verbena stricta } \\
\text { Hoary vervain }\end{array}$ \\
\hline $\begin{array}{l}\text { Bouteloua gracilis } \\
\text { Blue grama }\end{array}$ & $\begin{array}{l}\text { Amorpha canescens } \\
\text { Lead plant }\end{array}$ & $\begin{array}{l}\text { Chamaesyce maculata } \\
\text { Spotted spurge }\end{array}$ \\
\hline $\begin{array}{l}\text { Bouteloua hirsuta } \\
\text { Hairy grama }\end{array}$ & $\begin{array}{l}\text { Silene antirrhina } \\
\text { Sleepy catchfly }\end{array}$ & $\begin{array}{l}\text { Tragopogon pratensis } \\
\text { Yellow goat's beard }\end{array}$ \\
\hline $\begin{array}{l}\text { Festuca octoflora } \\
\text { Six-weeks fescue }\end{array}$ & $\begin{array}{l}\text { Achillea occidentalis } \\
\text { Yarrow }\end{array}$ & $\begin{array}{l}\text { Chenopodium album } \\
\text { Lamb's quarters }\end{array}$ \\
\hline $\begin{array}{l}\text { Sorghastrum nutans } \\
\text { Indian grass }\end{array}$ & $\begin{array}{l}\text { Cirsium undulatum } \\
\text { Wavy-leaved thistle }\end{array}$ & $\begin{array}{l}\text { Amaranthus retroflexus } \\
\text { Rough pigweed }\end{array}$ \\
\hline $\begin{array}{l}\text { Panicum scribnerianum } \\
\text { Scribner's panic grass }\end{array}$ & $\begin{array}{l}\text { Vernonia baldwini } \\
\text { Ironweed }\end{array}$ & $\begin{array}{l}\text { Salsola pestifer } \\
\quad \text { Russian thistle }\end{array}$ \\
\hline $\begin{array}{l}\text { Sporobolus heterolepis } \\
\text { Prairie dropseed }\end{array}$ & $\begin{array}{l}\text { Gaura parviflora } \\
\text { Small-flowered gaura }\end{array}$ & $\begin{array}{l}\text { Ambrosia psilostachya } \\
\text { Western ragweed }\end{array}$ \\
\hline $\begin{array}{l}\text { Sporobolus asper } \\
\text { Tall dropseed }\end{array}$ & $\begin{array}{l}\text { Kuhnia glutinosa } \\
\text { Prairie false boneset }\end{array}$ & $\begin{array}{l}\text { Panicum capillare } \\
\text { Witchgrass }\end{array}$ \\
\hline $\begin{array}{l}\text { Cyperus filiculmis } \\
\text { Slender cyperus }\end{array}$ & $\begin{array}{l}\text { Psoralea argophylla } \\
\text { Silvery psoralea }\end{array}$ & \\
\hline $\begin{array}{l}\text { Panicum virgatum } \\
\text { Tall panic grass }\end{array}$ & $\begin{array}{l}\text { Baptisia bracteata } \\
\text { False indigo }\end{array}$ & \\
\hline $\begin{array}{l}\text { Panicum wilcoxianum } \\
\text { Wilcox's panic grass }\end{array}$ & $\begin{array}{l}\text { Petalostemon purpureus } \\
\text { Purple prairie clover }\end{array}$ & \\
\hline $\begin{array}{l}\text { Eragrostis spectabilis } \\
\text { Purple lovegrass }\end{array}$ & $\begin{array}{l}\text { Astragalus crassicarpus } \\
\text { Ground plum }\end{array}$ & \\
\hline Native Forbs & $\begin{array}{l}\text { Acerates angustifolia } \\
\text { Narrow-leaved milkweed }\end{array}$ & \\
\hline $\begin{array}{l}\text { Hedeoma hispida } \\
\text { Rough pennyroyal }\end{array}$ & $\begin{array}{l}\text { Psoralea floribunda } \\
\text { Many-Hlowered psoralea }\end{array}$ & \\
\hline $\begin{array}{l}\text { Plantago purshii } \\
\text { Pursh's plantain }\end{array}$ & $\begin{array}{l}\text { Vicia americana } \\
\text { American vetch }\end{array}$ & \\
\hline $\begin{array}{l}\text { Solidago glaberrima } \\
\text { Smooth goldenrod }\end{array}$ & $\begin{array}{l}\text { Equisetum laevigatum } \\
\text { Smooth scouring-rush }\end{array}$ & \\
\hline $\begin{array}{l}\text { Erigeron ramosus } \\
\text { Daisy tleabane }\end{array}$ & & \\
\hline
\end{tabular}

spring rainfall, 1938, 1942, and especially in 1943, when an average of 1,000 plants per sq. dm. was found. Other ruderals occurred only in small numbers.

\section{Succession in Quadrats Dominated By Litthe Bluestem}

Changes in plant population in 10 quadrats in which Andropogon scoparius was the most abundant grass are shown for each year of succession in Table 4. It formed 31 percent of the total grass population in 1937. Number of stems increased 96, 90, and 16 percent over the preceding year, respectively. But other grasses also increased so that this species formed 39 percent of the total grass cover in 1940 (Fig. 7). There was a decrease the next year but 


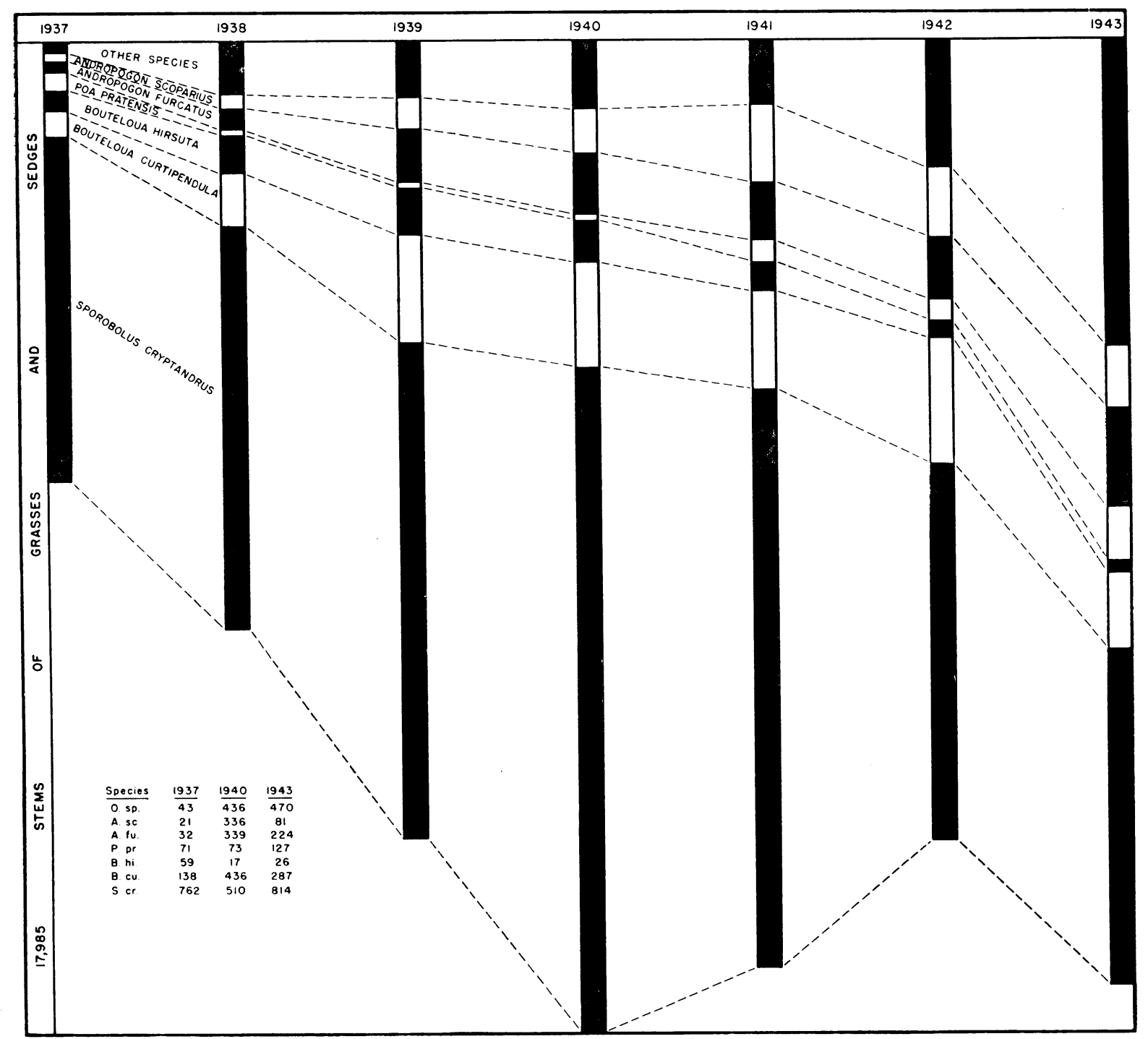

Fig. 6. Data from quadrats of Sporobolus cryptandrus. (Left) Maximum number of stems of perennial grasses and sedges, and (vertical columns) relative abundance in 1937 to 1943 inclusive. The table gives the number of square decimeters in which each species occurred at the beginning of the study, near the end of the lrought (1940), and after 2 years favorable to growth.

steady increase thereafter. The gain over the 7 -year period was 365 percent. Despite this great gain in number of stems, the plants occurred in fewer square decimeters (352) than they did in 1937 (397). This resulted from the severe fall and winter drought of 1939-40 when many bunches died.

Behavior of Sporobolus cryptandrus is of special interest under the competition afforded by the thickening regetation. It increased 75 percent in 1938, 19 percent more in 1939 , and an additional 31 percent by 1940, despite the dry fall preceding 1940 which resulted in decrease of Andropogon furcatus and Bouteloua curtipendula. Although it continued to increase in 1941, there was a great loss in stems the next summer. This species usually ranked second in abundance until 1941. Then, owing to a large crop of seedlings, it greatly surpassed Andropogon scoparius in number of stems for a single year, after which its population greatly declined. It was only about one third as abundant as the dominant in 1943, but it nearly doubled its numbers during the seven years. In 1940 and 1943 it occurred in 510 or more unit areas, compared with only 373 at the first quadratting.

Bouteloua curtipendula, like sand dropseed, illustrated its xeric nature by good increases until 1940, when it had gained 367 percent. It decreased about one third by 1943 . Gains during the 7 years were 210 percent in stem numbers, and from 221 to 395 in unit areas in which it occurred. Andropogon furcatus increased in a manner similar to that of little bluestem until 1940. It declined somewhat in 1940 and 1941 but recovered considerably in 1943. Total gain by 1940 was 287 percent over that of 1937 , and 
TABLE 4. Species of grasses and sedges, native forbs, and ruderals in 10 meter quadrats where Andropogon scoparius was the most abundant species in 1937, and changes in plant populations during each year of succession.

\begin{tabular}{|c|c|c|c|c|c|c|c|c|}
\hline \multirow{2}{*}{ Species } & \multicolumn{7}{|c|}{ Number of Stems } & \multirow{2}{*}{ 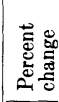 } \\
\hline & 1937 & 1938 & 1939 & 1940 & 1941 & 1942 & 1943 & \\
\hline Grasses and Sedges & & & & & & & & \\
\hline Andropogon scoparius. & 2,048 & 4,014 & 7,606 & 8,849 & 8,153 & 8,503 & 9,521 & 365 \\
\hline Sporobolus cryptandrus & 1,714 & 3,006 & 3,565 & 4,660 & 13,586 & 3,522 & 3,313 & 93 \\
\hline Bouteloua curtipendula & 748 & 2,378 & 3,813 & 3,492 & 3,133 & 2,537 & 2,319 & 210 \\
\hline Andropogon furcatus. . & 741 & 1,634 & 3,114 & 2,871 & 2,457 & 2,755 & 3,151 & 325 \\
\hline Poa pratensis....... & 713 & 131 & 343 & 331 & 463 & 1,480 & 2,863 & 302 \\
\hline Carex pennsylvanica. & 308 & 399 & 645 & 880 & 655 & 637 & 1,528 & 396 \\
\hline Koeleria cristata..... & 273 & 550 & 541 & 636 & 522 & 1,234 & 1,486 & 444 \\
\hline The 10 other grasses & 117 & 950 & 1,001 & 1,172 & 1,616 & 1,048 & 818 & 599 \\
\hline Total. . & 6,662 & 13,062 & 20,628 & 22,891 & 30,585 & 21,716 & 24,999 & 275 \\
\hline Native Forbs & & & & & & & & \\
\hline Plantago purshii.. & 656 & 715 & 371 & 30 & & 0 & & -100 \\
\hline Hedeoma hispida. & 443 & 1,007 & 830 & 44 & 5 & 1 & 75 & -83 \\
\hline Erigeron ramosus. & 125 & 145 & 31 & 6 & 254 & 31 & 407 & 226 \\
\hline Aster multiflorus. . & 94 & 179 & 451 & 483 & 476 & 318 & 140 & 49 \\
\hline The 12 other forbs. & 71 & 128 & 115 & 79 & 36 & 53 & 213 & 200 \\
\hline Total... & 1,389 & 2,174 & 1,798 & 642 & 772 & 403 & 838 & -40 \\
\hline $\begin{array}{c}\text { RUDERALS } \\
\text { Leptilon canadense... }\end{array}$ & 3,932 & 670 & 99 & & 0 & 49 & 3,287 & -16 \\
\hline Lepidium densiforum. & 2,210 & $\begin{array}{r}52 \\
\end{array}$ & 4 & 62 & 2 & 0 & 0 & -100 \\
\hline The 15 other ruderals. & 22 & 81 & 40 & 70 & 45 & 40 & 39 & 77 \\
\hline Total... & 6,164 & 803 & 143 & 135 & 47 & 89 & 3,326 & -46 \\
\hline
\end{tabular}

it increased still more in 1943. These gains were accompanied by an increase in area occupied (Fig. 7). Poa pratensis, Carex pennsylvanica, and Koeleria cristata all increased greatly after 1941 when soil moisture became more plentiful.

The most striking changes in these quadrats were the great gains made by little bluestem; the early steady gains of sand dropseed and its great increase after the 1939-40 drought at a time when nearly all other grasses decreased; and, finally, the increase of nearly all other species thereafter. The total increase among the grass life-form was 275 percent.

Among the forbs, Plantago purshii, Hedeoma hispida, and Erigeron ramosus alone were of much importance in 1937. They all decreased greatly by 1940, but only Erigeron became more abundant with greater precipitation. Aster multiflorus at first increased under protection from grazing, remained almost stationary for 3 years, and then declined rapidly with the thickening of the grasses.

Certain ruderals in 1937 were as abundant as the grasses. Leptilon canadense and Lepidium densiflorum were most abundant, but soon greatly decreased and later disappeared. Total reduction of ruderals was 98 percent by 1940 , and except for Leptilon they were even fewer in 1943. But Leptilon reappeared in very large numbers.

\section{Succession in Quadrats Dominated BY Kentucky Bluegrass}

Poa pratensis suffered great losses, often amounting to more than 95 percent, following the great drought of 1934. It remained in small patches of a square meter or less in the pasture when cattle were excluded. Of the 25,000 stems of grasses found in the 10 quadrats, 23,000 were bluegrass. All other species constituted but 8 percent of the grass population (Table 5). With a loss of 99 percent of the bluegrass during the dry fall and winter of 1937-38, the total cover of grasses was reduced to 31 percent by the next summer, despite the great gains of all of the other species. By 1940 bluegrass, which had occurred in $730 \mathrm{sq}$. dm. units, was found sparingly in only 196. Thus, much fertile soil had been laid open to the other species. All of the other grasses showed good gains in 1939 , but nearly all decreased in 1940. Sporobolus cryptandrus, however, gained steadily until 1941 when, like most other species, it showed a decrease. The net loss for bluegrass (1937. 41) was 96 percent. All others gained from 358 to 939 percent-the 8 other grasses collectively, much more. Moreover, all had increased their area of occupation. After 1941 bluegrass increased so rapidly that further stem counts seemed impracticable, in fact its return by rhizome propagation was extremely rapid during the years favorable for growth.

TABLE 5. Species of grasses and sedges, native forbs, and ruderals in 10 meter quadrats dominated in $1937 \mathrm{by}$ Poa pratensis, and changes in plant populations during each of the five years of protection.

\begin{tabular}{|c|c|c|c|c|c|c|}
\hline \multirow{2}{*}{ Species } & \multicolumn{5}{|c|}{ Number of Stems } & \multirow{2}{*}{$\begin{array}{l}\text { Percent } \\
\text { change }\end{array}$} \\
\hline & 1937 & 1938 & 1939 & 1940 & 1941 & \\
\hline Grasses and Sedges & & & & & & \\
\hline Poa pratensis........... & 23,085 & 205 & 1,755 & 1,371 & 974 & -96 \\
\hline Sporobolus cryptandrus. & 751 & 3,194 & 3,279 & 4,140 & 4,028 & $\mathbf{4 3 6}$ \\
\hline Andropogon furcatus... & 450 & 1,112 & 3,092 & 2,576 & 2,687 & 497 \\
\hline Andropogon scoparius. . & 369 & 1,000 & 2,155 & 2,537 & 1,689 & 358 \\
\hline Bouteloua curtipendula. & 268 & 1,175 & 3,052 & 2,737 & 2,308 & 761 \\
\hline Carex pennsylvanica ... & 129 & 520 & 1,071 & 1,661 & 1,340 & 939 \\
\hline The 8 other grasses.... & 26 & 659 & 1,352 & 948 & 1,082 & 4,062 \\
\hline Total & 25,078 & 7,865 & 15,756 & 15,970 & 14,108 & -44 \\
\hline Native Forbs & & & & & & \\
\hline Hedeoma hispida..... & 195 & 140 & 28 & 37 & $\begin{array}{r}169 \\
279\end{array}$ & $\begin{array}{l}-13 \\
1421\end{array}$ \\
\hline Aster multiflorus...... & 163 & 362 & 1,333 & $\begin{array}{l}1,198 \\
304\end{array}$ & 2,479 & 1,421 \\
\hline The 17 other forbs.... & 416 & 396 & 598 & 304 & 1,291 & \\
\hline Total & 774 & 898 & 1,959 & 1,539 & 3,939 & 409 \\
\hline Ruderals & & & & & & \\
\hline Leptilon canadense.... & 2,923 & 80 & 7 & 22 & 14 & -100 \\
\hline The 13 other ruderals. . & 608 & 166 & 179 & 94 & 275 & $-\quad 55$ \\
\hline Total. & 3,531 & 246 & 186 & 116 & 289 & - \\
\hline
\end{tabular}

Native forbs were not abundant in the bluegrass sod, nor did they greatly increase with the death of bluegrass, except Aster multiflorus, which increased 635 percent by 1940 and 107 percent the next year. The most abundant ruderal was Leptilon canadense, which decreased after 1937 to very small numbers.

\section{Succession in Other Quadrats}

Changes in the plant population in 10 quadrats in which mats of Bouteloua gracilis occurred were ascertained. The outline of the blue grama mats in 


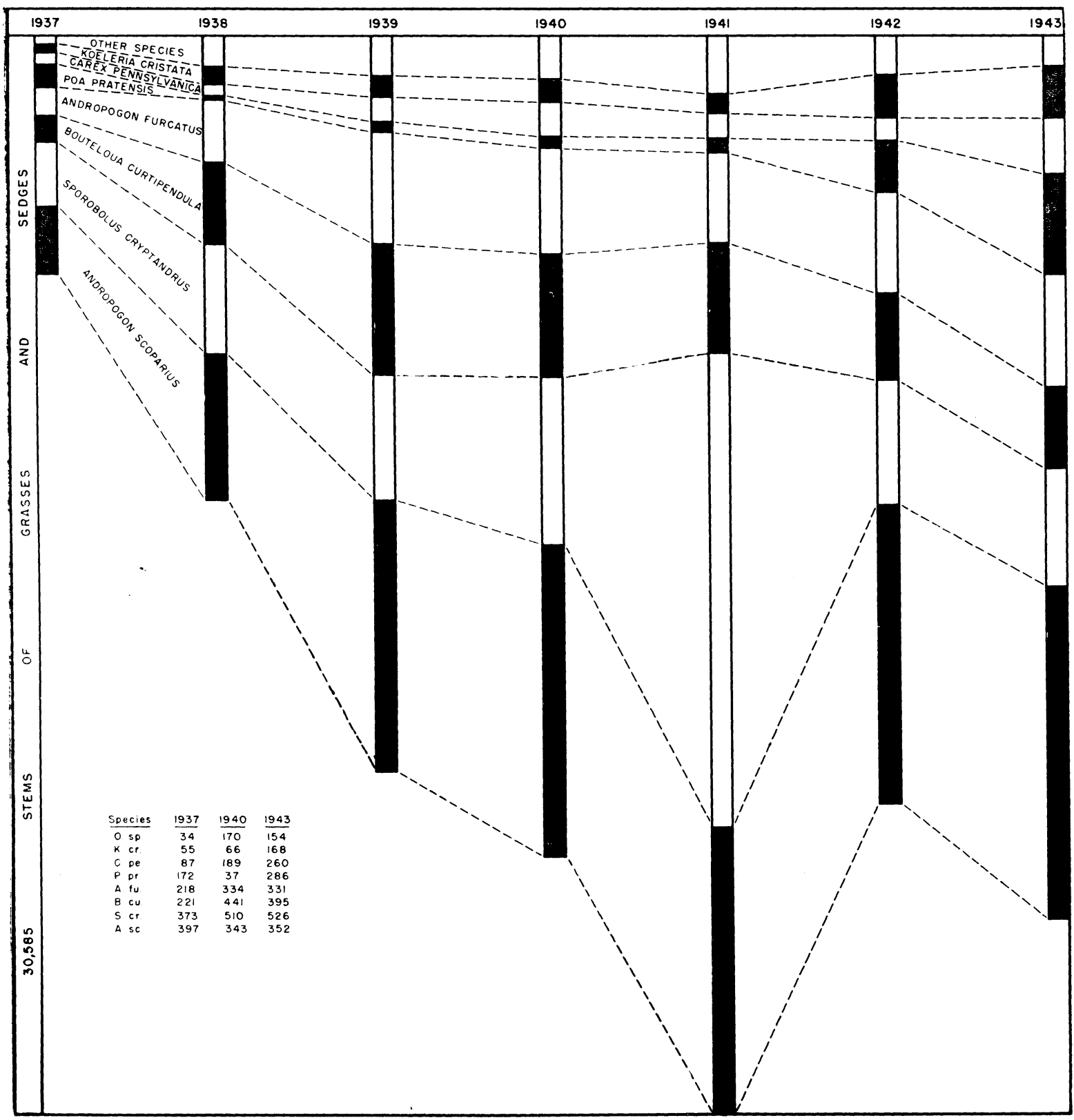

FI(. 7. Data from quadrats of Andropogon scoparius. (Left) Maximum number of stems of perennial grasses and sedges, and (vertical columns) relative abundance in 1937 to 1943 inclusive. Table as in Figure 6.

the several quadrats included approximately 8 to 64 percent of the square meter, but the basal area was much less than this, since long continued grazing had resulted in very open short-grass vegetation. The basal area occupied by blue grama was ascertained annually, each square decimeter being estimated separately. It was $6,12,12$, and 16 percent in the years 1937 to 1940 , respectively. Since 420 unit areas contained this species originally but 487 finally, the increase in basal area was due largely to a thickening of the mats. In 1941 the basal area was only 13 percent, but a year later it had increased to 23. Blue grama then occurred in 585 units. Kinds and behavior of species of grasses, forbs, and ruderals were very similar to those in preceding quadrats. Sand dropseed, the most abundant mid grass, increased 136 percent by 1940 , side-oats grama 242 , big bluestem 276, little bluestem 312 , but bluegrass only 45 percent.

Three quadrats where the soil was barest under the almost continuous stand of Lepidium densiflorum were also selected for study. Death of the hluegrass especially, but also of many other plants, produced these nearly bare places. Here the annual peppergrass grew, but for one season only, at the rate of 600 to 700 plants per square meter. The seourge of this weed in both pasture and drought-stricken praire was general from the Missouri River westward to 
the Rocky Mountains (Weaver and Albertson, 1939). Hordeum pusillum occurred frequently, increased almost 900 percent the second year, waned in 1939, but reached its greatest abundance (1,900 stems per square meter) in 1940 . Other weeds were only moderately abundant, especially Leptilon canadense, Grindelia squarrosa, and Verbena stricta. Native forbs were of little significance, although Plantago was common.

Under this canopy, Sporobolus cryptandrus had 322 stems per square meter. It doubled this number the next year, showed a slight decrease in 1938, but a total increase of 137 percent for the four summers ending in 1940. Poa pratensis entirely disappeared, Carex pennsylvanica inereased 106 percent, and Bouteloua curtipendula 280 percent, although it decreased in 1939. Andropogon furcatus increased from 6 stems to 54. Cyperus filiculmis entered the plots in 1938 , flourished in 1939, but lost half its numbers in 1940. Only 12 grass seeedlings, all sand dropseed, were found in these plots during the four summers.

\section{Summary of Succession in Ali Quadrats}

Changes in plant populations in the 43 quadrats taken collectively are shown from 1937 to 1941 in Table 6 and Figure 8 . Poa pratensis comprised 56 percent of the total grasses in 1937. Greatly weakened by drought, it was reduced to only 3 percent of its 1937 abundance by 1938 . It increased about 3.5 times by 1939 , but lost slightly the two following years. By 1941, however, there was 223 percent more than in 1938. It was represented in 1,049 unit areas in 1937 but in only 320 in 1941. In 1942 it made an excellent recovery and the next year its gains were very great; large patches were dominated by bluegrass and an understory of this species occurred widely.

Sporobolus cryptandrus composed 26 percent of the grasses in 1937. It gained consistently in numbers year by year; in thousands of stems the gains were from 11 to 17 and then to 20 and 26 , and finally to 32. Yearly gains in percentages were 55, 19, 29, and 20. Total increase in number of stems was 185 percent. Since its gain in square decimeters occupied was only 112 by 1940, its chief development was that of plants already established, although seedlings occurred far more abundantly than those of any other grass. Moreover, its wide initial distribution in more than 43 percent of the unit areas should be emphasized. The spread into 954 additional units in 1941 was due largely to seedlings. But with the increasing abundance of the more mesic and more shade-enduring grasses after 1941, there was a gradual but regular decline, as was indicated by data from the quadrats charted each year, inrluding 1943.

Andropogon scoparius increased 105 percent the first year, 98 the second, and 17 in 1940. Thus, the total gain was 375 percent, but the increase in area of this bunch grass was only from 549 to 822 units. Very few seedling bluestems of either species were found. There was a slight decrease in 1941, but

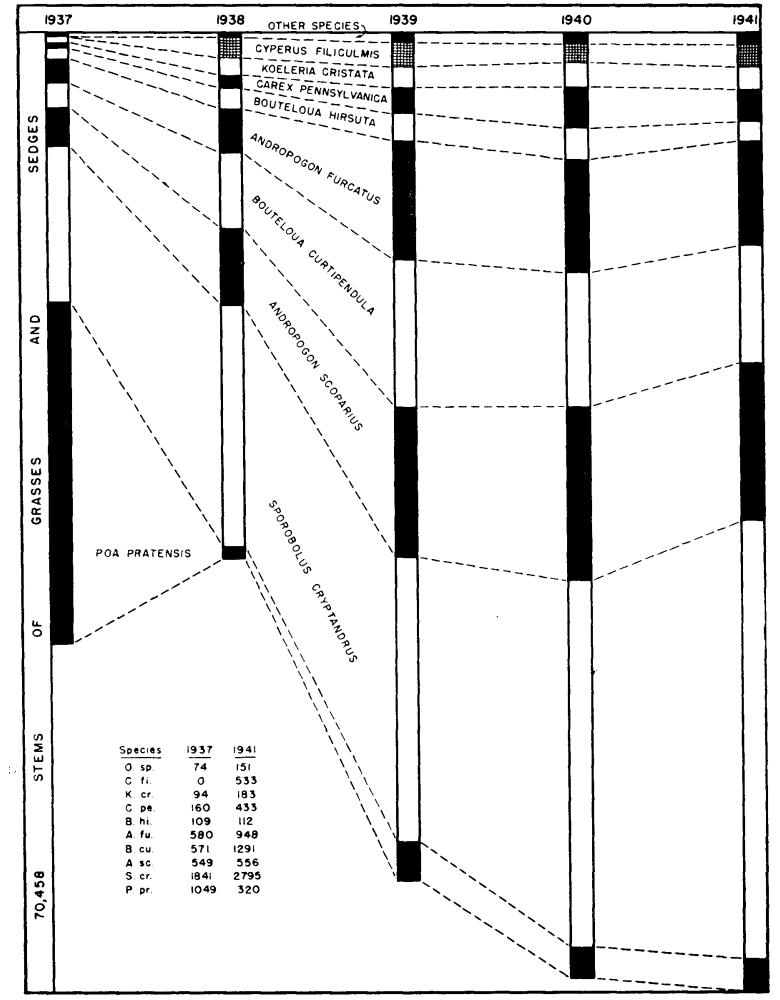

Fig. 8. Data from all 43 quadrats. (Left) Maximum number of stems of perennial grasses and sedges, and (vertical columns) relative abundance in 1937 to 1941 inclusive. The table gives the number of square decimeters in which each species occurred at the beginning of the study and at the end of the drought (1941).

thereafter widely scattered and long-dormant crowns revived, old bunches became filled with stems and also increased their area, and seedlings began to appear (Weaver and Albertson, 1944). Thus, with a revival of the bluestems, and the spreading of the bluegrass, sand dropseed was suppressed.

Bouteloua curtipendula increased even more rapidly than did sand dropseed. Gains were 195 and 91 percent, respectively, in the first 2 years. But these were followed by decreases of 9 and 11 percent in 1940 and 1941 respectively. This phenomenon of a great wave of side-oats grama sweeping over the drought-opened prairie following the good year of 1938 was general, as was also its waning following the fall and winter drought of 1939-40 (Weaver, 1943). Nor did it ever again reach such great abundance, for with increased precipitation the more mesic and more shade-tolerant grasses began to reduce it to its former role of an interstitial species (Weaver and Albertson, 1944). The 4-year gain, however, was 356 percent. It spread from an initial area of 571 units to 1,291 .

Andropogon furcatus likewise gained rapidly, 106 and 144 percent the first 2 years. It then decreased 8 and 5 percent the next two. Its total gain by 1941 was 337 percent, and it spread from 580 to 1,245 unit areas by 1940, but decreased to 948 in 1941 . But once the soil became more constantly moist, the 
TABLE 6. Summary of species of grasses and sedges, native forbs, and ruderals in the 43 meter quadrats, and changes in plant population during each of the 5 years of protection.

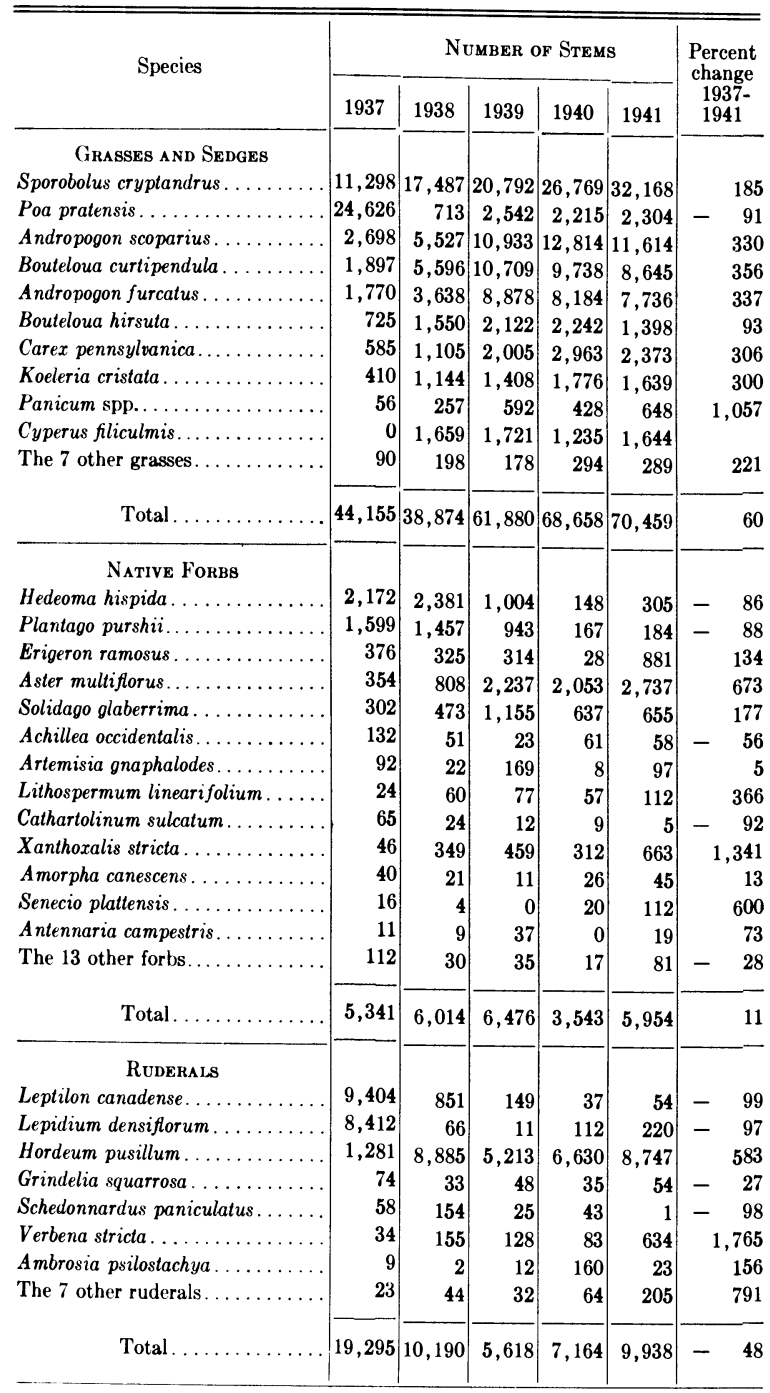

plants flourished. Their shade was distinctly harmful to sand dropseed.

Boutelona hirsuta, Carex pennsylvanica, Koeleria cristata, and Cyperus filiculmis all increased steadily in number of stems, except for a slight decrease in 1940 or 1941. All but Bouteloua also increased greatly in number of unit areas occupied.

Among the 26 native forbs growing in the quadrats, only 5 were of outstanding abundance. Together they constituted 90 percent of the total forb population in 1937, and 80 percent in 1941. Contrary to the decrease in most grasses in 1941, the forbs, with few exceptions, increased in numbers. The slight increase in Hedeoma hispida in 1938 and the marked decrease in 1940 is shown in Table 6 . The behavior of Plantago purshii, second in abundance, was somewhat similar. Erigeron had made an enormous increase everywhere in pasture and prairie following the drought year of 1934 and was just beginning to decline in 1937-38. Solidago glaberrima and especially Aster multiflorus spread widely by rhizomes. Number of stems increased 57 and 128 percent respectively the first year, and 144 and 177 percent the second, after which there was a decrease in both species as the grass population became denser. This was followed by a slight increase in 1941. The net increases from 1937 to 1940 were 111 percent for goldenrod and 480 for aster. Much of this was an actual spreading into new territory. The total forb population increased 13 percent the first year and 8 the second. Then followed a heavy loss of 45 percent in 1940, after which there was a gain of 68 percent. Of the five leading species in 1937, the three short-lived annuals ranking highest were far surpassed in abundance in 1940 by Aster multiflorus and Solidago glaberrima. Number of species of forbs in the plots was reduced from 19 in 1937 to 15 in 1940, but in 1941 there were 26 . Decrease in kind and number of forbs was general in grassland following the great drought.

Among the 14 species of ruderals encountered in quadratting, only three were of outstanding abundance (Table 6). They constituted 99 percent of the weedy fraction of the vegetation in 1937. Leptilon canadense alone formed 49 percent, and $L e-$ pidium densiflorum 44 . Leptilon decreased 91 percent the first year and Lepidium 99. Thereafter neither was of much significance. Formerly occurring in an area of about 2,500 square decimeters, they were finally reduced to 50 or less. This remarkable change is to be attributed very largely to seasonal differences in physical environment and not to the cumulative competitive effect of a denser grass cover. It occurred in drought-depleted prairie as well as in pasture.

Total weed population was not reduced in 1938 in proportion to these two weeds. Hordeum pusillum increased sufficiently (594 percent) to maintain the general loss from 1937 at 47 percent. In 1938, this weed alone composed 87 percent of the ruderals. It decreased the next year, but was again abundant in 1940, and even more abundant in 1941. Since the number of other species collectively remained fairly constant, the rise or decline of weeds after 1937 was determined almost entirely by Hordeum. At its lowest ebb in 1939, the total weed population had decreased to 70 percent of that of 1937 . The number of unit areas in which weeds occurred decreased from approximately 5,500 to 700 . But both number of stems and unit areas occupied increased with drought. Thus, in 1941 the decrease in number of stems over 1937 was only 48 percent.

\section{Occurrence of Seedlings}

The number and kind of seedlings found in the quadrats were recorded each season. Because of the intermittent periods of drought that occurred nearly every year, seedling population was small considering the openness of the vegetation, especially during the earlier years of succession (Weaver and Mueller, 1942). Table 7 shows that among the perennial grasses there were no seedlings the first year, and that 
Sporobolus cryptandrus was by far the most prelific seeder. The largest number of seedlings occurred in 1941 when there was abundant moisture until July. Of these 93 percent $(10,114)$ were Sporobolus cryptandrus. Not only was the total number much greater, but seedlings of 6 additional grasses and 7 forbs were found.

TABLE 7. Kind and number of seedlings in the 43 quadrats when listed in June or July of each year.

\begin{tabular}{|c|c|c|c|c|c|c|c|}
\hline Species & 1937 & 1938 & 1939 & 1940 & 1941 & $1942^{*}$ & $1943^{*}$ \\
\hline $\begin{array}{c}\text { Perennial Grasses } \\
\text { Sporobolus cryptandrus.... }\end{array}$ & & 390 & 350 & 255 & 10,114 & 9 & 2 \\
\hline Andropogon scoparius..... & & & 6 & 4 & 38 & & 1 \\
\hline Bouteloua curtipendula... & & … & 51 & 30 & 183 & 36 & 34 \\
\hline Andropogon furcatus.... & & & 4 & 19 & 211 & 4 & 1 \\
\hline Bouteloua hirsuta. ... & & ... & 18 & . & 14 &. & 4 \\
\hline Koeleria cristata..... & & 25 & 3 & 4 & 41 & 27 & 161 \\
\hline Panicum scribnerianum. & & & 3 & 18 & 282 & 16 & 31 \\
\hline Six other species....... & & & & $\ldots \ldots$ & 24 & 9 & 4 \\
\hline Total.... & & 415 & 435 & 330 & 10,907 & 101 & 238 \\
\hline Native Forbs & & & & & & & \\
\hline Erigeron ramosus...... & 176 & 61 & 1,051 & 347 & 802 & 21 & 14 \\
\hline Aster multiflorus.......... & $\ldots$ & 9 & 25 & 33 & 406 & 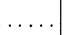 & .. \\
\hline Cirsium undulatum......... & 8 & 3 & 6 & 2 & 6 & & .. \\
\hline Achillea occidentalis........ & 1 & 53 & 71 & 13 & 1 & 18 & 2 \\
\hline Lithospermum linearifolium & & & 17 & 123 & 60 & & . \\
\hline Xanthoxalis stricta ........ & & . & & 161 & 225 & 1 & 6 \\
\hline Eight other species........ & 4 & 12 & & & 109 & & . \\
\hline Total. & 189 & 138 & 1,170 & 679 & 1,609 & 40 & 22 \\
\hline Ruderals & & & & & & & \\
\hline Leptilon canadense.. . & & & 4 & 18 & 184 & & 3 \\
\hline Grindelia squarrosa.... & 19 & & 87 & 181 & 43 & & . . \\
\hline Verbena stricta............ & 12 & 4 & 11 & 48 & 236 & & . \\
\hline Chamaesyce maculata...... & 1 & 13 & 3 & 7 & 32 & & . \\
\hline Amaranthus retroflexus...... & 2 & 3 & . & 7 & 13 & & $\ldots \ldots$ \\
\hline Salsola pestifer............ & & 1 & 11 & 151 & 77 & & $\ldots \ldots$ \\
\hline Total...... & 34 & 21 & 116 & 412 & 585 & & 3 \\
\hline
\end{tabular}

*Data from 20 quadrats only.

In 1942 only 101 seedlings of grasses and 40 of native forbs occurred in the 20 meter quadrats. The number of seedlings was also low under the heavy cover of vegetation in 1943, although a good seed crop matured in 1942. In fact, the slowness of recovery was due in part to the small number of seedlings. After years of drought, an abundance of seedlings must be preceded by a good seed crop. Seeds of the several grasses were planted in six different places selected at random after spring mowing in 1942. They were worked into the soil by means of a garden rake. Excellent stands were produced. The plants grew slowly, and nearly all appeared dead after the August drought. Many were revived by the autumn rains, but growth was negligible. Only rarely did one survive under the dense foliage cover of the following year.

Although the living seedlings were included in the stem counts, except for Sporobolus cryptandrus they were nearly always few. Consequently the increase in perennial plants was due to tillering, production of shoots from rhizomes, or other means of vegetative propagation, and after 1942 by growth from longdormant rooterowns and rhizomes (Weaver, 1944).

\section{OTHER MEASURES OF SUCCESSION}

The progressive development of the vegetation was ascertained by several other methods. These included the measurement of density and composition, size and character of bunches, relative vigor as expressed following clipping, yield, and repeated general observations.

\section{Density and Composition of Vegetation}

Data were obtained upon the density and composition of vegetation in areas which had undergone different periods of succession. Five meter quadrats were selected at random but approximately opposite each other, in each of the several long, narrow exclosures where succession had proceeded a first, second, and fourth year respectively. This was done on June 15, 1940. Foliage cover was estimated separately by each of three experienced investigators after each quadrat had been divided into five strips, each 2 decimeters wide. Experience has shown that this is the best size of area for this purpose in this type of vegetation. The three estimates for each 2-decimeter strip were averaged, and then added and divided by five in order to obtain the total foliage cover for each square meter. Foliage cover is equivalent to the percentage of soil surface that is concealed by the vegetation when the estimator views the plants directly from above. Basal area was estimated for each square decimeter, that is, 100 estimates were made and averaged for each quadrat.

Stems were listed in the usual manner. Percentage composition of vegetation was ascertained by dividing each quadrat into 10 decimeter strips and considering the total vegetation in each as 100 percent. Two investigators, working together, then estimated what percentage of the entire vegetation was constituted by sand dropseed, little bluestem, etc. This was based solely on area occupied by the bases of bunches or stems of each species. Forbs were estimated collectively.

The foliage cover shows some irregularities, as would be expected in random sampling. There is a marked increase in average cover during the second years of succession-a gain of 93 percent (Table 8).

TABLE 8. Percentage of foliage cover and basal area of pasture vegetation on June 15, 1940, during the first, second, and fourth year of succession.

\begin{tabular}{|c|c|c|c|c|c|c|}
\hline \multirow{2}{*}{$\begin{array}{c}\text { Quadrat } \\
\text { No. }\end{array}$} & \multicolumn{3}{|c|}{ Foliage Cover } & \multicolumn{3}{|c|}{ Basal Area } \\
\hline & $\begin{array}{l}\text { First } \\
\text { Year }\end{array}$ & $\begin{array}{c}\text { Second } \\
\text { Year }\end{array}$ & $\begin{array}{c}\text { Fourth } \\
\text { Year }\end{array}$ & $\begin{array}{l}\text { First } \\
\text { Year }\end{array}$ & $\begin{array}{c}\text { Second } \\
\text { Year }\end{array}$ & $\begin{array}{c}\text { Fourth } \\
\text { Year }\end{array}$ \\
\hline $\begin{array}{l}1 \ldots \ldots \\
2 \ldots \ldots \\
3 \ldots \ldots \\
4 \ldots \ldots \\
5 \ldots \ldots\end{array}$ & $\begin{array}{l}46 \\
24 \\
36 \\
25 \\
16\end{array}$ & $\begin{array}{l}58 \\
56 \\
76 \\
60 \\
32\end{array}$ & $\begin{array}{l}72 \\
60 \\
49 \\
64 \\
61\end{array}$ & $\begin{array}{r}12.2 \\
11.3 \\
14.8 \\
7.2 \\
6.9\end{array}$ & $\begin{array}{l}21.0 \\
19.0 \\
22.8 \\
28.1 \\
15.3\end{array}$ & $\begin{array}{l}18.2 \\
16.5 \\
20.8 \\
22.0 \\
20.7\end{array}$ \\
\hline Average. . & 29 & 56 & 61 & 10.5 & 21.2 & 19.6 \\
\hline
\end{tabular}


This increase in the amount of vegetation is also expressed in a somewhat comparable increase (102 percent) in basal area. Increase in foliage cover from the second to the fourth year was only 9 percent, and the basal area decreased slightly. This decrease is attributed largely to partial replacement of the wide-based sand dropseed by the more erect bluestems and side-oats grama, but in part to the more erect habit of sand dropseed under competition.

Basal area the fourth year varied from 16.5 to 22 percent and averaged 19.6. In the original pasture recently protected it varied from 6.9 to 14.8 percent and averaged 10.5. Thus, the amount of soil covered in the fourth year of the succession was nearly double that in the original pasture.

The number of stems of sand dropseed showed an increase of 85 percent under the second year of succession as compared with the first. By the fourth year, however, the number had decreased until it was somewhat less than that of the first year. This behavior is in accord with the percentage composition. In the first year of protection sand dropseed alone constituted 49 percent of the grasses, in the second 81, but in the fourth year only 39 percent. This resulted in the rapid increase of this species immediately following protection and its actual decrease after four years resulting from the competition of other grasses, especially little bluestem and side-oats grama. Little bluestem about doubled its number of stems after one year of protection, but increased nearly 10 times by the fourth year. Increase of sideoats grama was also very great.

A very significant fact was the change in the composition of the vegetation upon the basis of basal area. The first year the non-weedy and practically wholly perennial grasses constituted 57 percent of the total vegetation. But this increased to 92 percent in the second year, and to 97 during the fourth year of succession. Ruderals showed a marked decrease from about 33 percent (mostly little barley) in the recently grazed pasture, to about 5 percent in the one protected two years. In the fourth year of succession the percentage of vegetation composed of ruderals had decreased to about 2 . The remaining increment of native forbs was 10,3 , and 1 percent, respectively, in the several stages of development.

\section{Size and Character of Bunches}

One hundred bunches of sand dropseed were selected at random in each of the three areas undergoing succession and in the adjacent grazed pasture. The diameter of the bunch one half inch above the soil surface was measured, and the number of stems per bunch was ascertained, as was also the length of stems. Bunches of little bluestem were similarly measured, 25 from each of the four habitats being used (Fig. 9). This was done on July 15, 1940, before flower stalks had appeared. The averages of these measurements are shown in Table 9.

Diameter of bunches of little bluestem gradually increased with the succession, but bunches of sand dropseed first increased and then became smaller. The smallest average diameter of sand dropseed

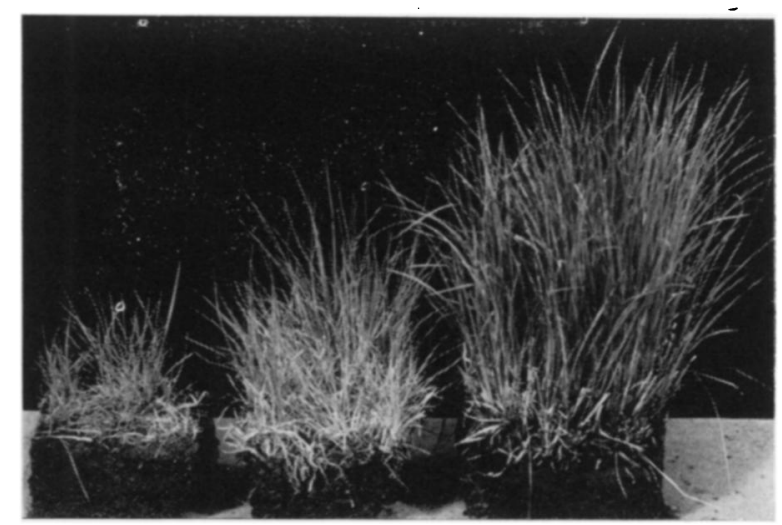

Fig. 9. Bunches of little bluestem (Andropogon scoparius) selected on June 13, 1940, for average size under the first, second, and fourth year of succession. Heights are $3,5.5$, and 9 inches respectively. The first bunch has only a fringe of stems on one side; the second is one fourth filled with stems; but the last has a dense stand of stems throughout. Dry weight of foliage in the same order is $2.5,11$, and 40 grams.

under protection was that of bunches having the largest number of stems. This resulted from the basal spreading habit of the grass under recent grazing and its more erect one under competition for light. Length of stems of both species increased rapidly and consistently under protection as did also their numbers. Stems of little bluestem practically doubled in number the first year of proctetion and almost repeated this increase the second growing season.

TABLE 9. Variation in size (in inches) and number of stems in bunches of grass of each species in grazed pasture and in the first, second, and fourth year of succession, respectively.

\begin{tabular}{|c|c|c|c|c|}
\hline \multirow{2}{*}{ Criteria } & \multirow{2}{*}{$\begin{array}{l}\text { Grazed } \\
\text { pasture }\end{array}$} & \multicolumn{3}{|c|}{ Year of Succession } \\
\hline & & First & Second & Fourth \\
\hline & \multicolumn{4}{|c|}{ Sporobolus cryptandrus } \\
\hline Diameter of bunch & 1.7 & 2.8 & 2.4 & 2.2 \\
\hline Number of stems.... & 6.7 & 12.5 & 15.4 & 19.9 \\
\hline Length of stems..... & 2.2 & 4.0 & 7.1 & 7.6 \\
\hline & \multicolumn{4}{|c|}{ Andropogon scoparius } \\
\hline Diameter of bunch ... & 1.5 & 2.2 & 2.3 & 2.9 \\
\hline Number of stems.... & 11.6 & 22.7 & 40.8 & 49.9 \\
\hline Length of stems. . . & 1.6 & 2.4 & 4.3 & 6.8 \\
\hline
\end{tabular}

Increase in foliage with increasing periods of succession also resulted in greater production and greater accumulation of litter. Average square meter areas under $0,1,2$, and 4 years of succession yielded respectively $31,56,88$, and 93 grams of air-dried litter. This increase in soil mulch is very beneficial, especially in relation to conservation of precipitation.

\section{Increase in Vigor of Vegetation in Relation to Period of Succession}

The increased vigor of vegetation as expressed by its rate of development after repeated removal of 
the foliage was studied. In an experiment where plants in quadrats had been removed by clipping on June 1, July 1, and again on August 15, their height on September 11 was ascertained (Table 10).

TABLE 10. Selected species of grasses showing relation between period of succession and recovery from elipping. Average height on September 11 is shown in inches.

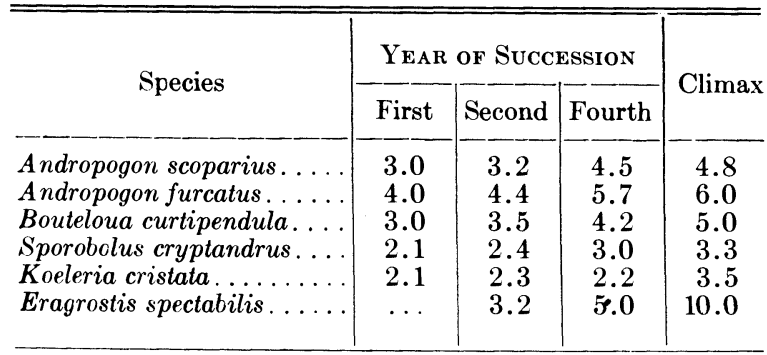

These data confirm other similar studies on recovery after clipping and reveal clearly the increasing vigor resulting from greater food reserves under an increasing period of succession without disturbance by grazing animals.

\section{Succession as Measured by Yield}

It is generally assumed that when climax true prairie degenerates to any one of the several subsere stages there is a corresponding decrease in either or both quantity and quality of forage. This is known to be a fact as regards degeneration of true prairie to Kentucky bluegrass, to western wheat grass, or to the short grasses-blue grama and buffalo grass (Buchloe dactyloides) (Weaver and Hougen, 1939; Weaver and Albertson, 1944). But to what degree, if any, plant production increases with succession is not so clear.

In the spring of 1940 a series of 30 meter quadrats were located at random 20 feet apart along a north-south line in the area undergoing its fourth year of succession. Thirty other quadrats were located in a similar manner in the adjoining climax prairie, and two other similar lots were laid out, one in the pasture undergoing a second year of succession and one in a parallel strip enclosed only in 1940. Clippings from these 4 groups of 30 quadrats were to supply data on the amount of prairie grasses, pasture grasses, and forbs, both native and ruderal, produced each month during summer. At each clipping the vegetation of each quadrat was separated by selective cutting into prairie grasses, pasture grasses, and forbs. Each partial yield was placed in a separate cloth sack, thoroughly air-dried, and its dry weight ascertained. Both prairie and pasture had been mowed about 1.5 inches high before growth was resumed and the grass collected with a hayrake and removed from the field.

Prairie grasses included all plants of grasslike habit that were found more or less regularly in normal, undisturbed prairie. Pasture grasses included similar species not common to climax eastern $\mathrm{Ne}-$ braska prairies, and bluegrass, which is a long- established invader. Only very small amounts of grasses not listed were found.

\begin{tabular}{ll}
\multicolumn{2}{c}{ Prairie Grasses } \\
Andropogon scoparius & Panicum virgatum \\
Andropogon furcatus & Panicum scribnerianum \\
Bouteloua curtipendula & Sorghastrum nutans \\
Bouteloua gracilis & Sporobolus asper \\
Bouteloua hirsuta & Sporobolus heterolepsis \\
Carex pennsylvanica & Stipa spartea \\
Koeleria cristata & \\
\multicolumn{2}{c}{ Pasture Grasses } \\
Aristida oligantha & Hordeum pusillum \\
Cyperus filiculmis & Hordeum jubatum \\
Eragrostis cilianensis & Poa pratensis \\
Eragrostis pectinacea & Sporobolus cryptandrus
\end{tabular}

The total seasonal yield in each stage of succession (from four monthly clippings) is shown in Table 11.

TABLE 11. Yield in grams of prairie grasses, pasture grasses, and forbs in areas where succession had proceeded the first, second, and fourth year respectively, and in climax prairie.

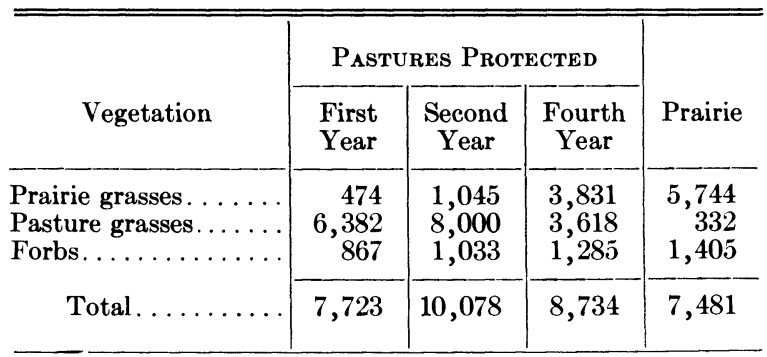

The annual yields of prairie grasses in percentages, based on the prairie as 100 percent and beginning with the first-year protection, were, respectively, 8.3, 18.2, 66.7, and 100. Annual yields of pasture grasses, based upon the first-year protection as 100 percent, were $100,125.4,56.7$, and 5.2 percent, respectively. Stating the yield of forbs in prairie as 100 percent, production in the pastures in the first to the fourth years of succession, was $61.7,73.5$, and 91.5 percent, respectively.

Comparison of the total yields reveals the surprising fact that they were greatest during the second year of succession. They were next greatest during the fourth year, less during the first year, and least in the climax prairie - which, however, had suffered considerably from drought. Yields per acre in the above sequence were $1.51,1.31,1.15$, and 1.12 tons. From these data on plant production near the end of a very dry period it may be clearly seen that the earlier stages in succession, where annual weeds and xeric grasses were plentiful, gave highest total yield.

During the end of the last year of experimental study (1943) and the second year of good rainfall, the total yield was again obtained. Ten 2-meter quadrats were selected at random at widely distributed places, previously unclipped, in the areas protected for the fourth and seventh year, respec- 
tively, and in the prairie. A first eutting was made on July 23 at a time when the vegetative growth of even the late blooming grasses was complete. The flower stalks of needle grass, June grass, Kentucky bluegrass, little barley, hairy chess (Bromus commutatus) and certain other plants were still standing or even if lodged could be included in the harvest. The bluestems, prairie dropseed, tall dropseed, and other late blooming grasses had not produced flower stalks. One of each of the 2-meter quadrats was used for determination of the basal area and both for the estimation of foliage cover. A second clipping was made in September, since a good growth of aftermath was produced. The new growth reached the average height of about 9 inches in all of the different experimental areas.

Basal area was 20 percent in the plots undergoing the fourth year of succession. This high amount was due in part to an understory of little barley. It was approximately the same ( 21.3 percent) in seven-year pasture and prairie. Foliage cover averaged 72 percent in each of the two former pastures and 80 percent in prairie. These high percentages and the great uniformity in the different areas showed that the vegetation had greatly improved since 1940 . Total yields in the 4-year and 7 -year pastures and in prairie, respectively, were $11,023,10,899$, and 11,513 grams; the prairie yielding 2.6 tons per acre.

From another lot of 20 meter quadrats in each of the three same experimental areas, but quadrats cut at the end of each of the four summer months, the total yields were, in the same order, $9,780,7,875$, and 8,461 grams. These heavy yields reflected both the rapid progress in succession and the improved condition for growth in 1942 and 1943. The fact that the yield of prairie grasses alone in the 4-year succession $(5,527$ g.) considerably exceeded that in the 7 -year $(5,003$ g.) and nearly equaled that of the prairie $(6,120$ g. $)$, at first appears anomalous. But the marked stimulation of the bluestems and other prairie grasses thinned by drought, as compared with those in relict prairie areas with a fair to good cover of vegetation, was a widespread phenomenon (Weaver and Albertson, 1944). With the return of moist years the less closely spaced relict grasses made a luxuriant growth; their stature far exceeded that of the same species in stabilized vegetation. In addition to this increased development of prairie grasses the excellent growth of pasture grasses as well increased the yield of the 4-year succession until it exceeded that of the climax grassland. At only one time during the 8-year period was the stand denser and the yield higher in any of these stages of succession or in the climax grassland. That was in the last year of the study, 1944.

\section{General Development of Vegetation}

In conjunction with the detailed study of the quadrats, a more comprehensive view of succession was gained by carefully recording each year the changes in the entire area'. The succession may stand out more clearly, however, if the vegetation during the second year (1938) is compared with that at the close of the drought cycle (1940-41), and this with the greatly improved plant cover after 3 years of recovery (1944).

PLANT COVER IN 1938

The second year of succession was one of good recovery of vegetation despite the midsummer drought. In the south exclosure there was a marked increase in grasses and a corresponding decrease in forbs. Big bluestem and little bluestem shared equally in importance with sand dropseed. There were many bunches, mostly small and young, of June grass and side-oats grama which had also increased in abundance. The bluestems and sand dropseed were not greatly intermixed but more or less dominated different local areas (Fig. 10). Aster and goldenrod were the most important weeds but, like all other perennial and annual forbs and weedy grasses, they were slowly giving way to the dominant grass lifeform.

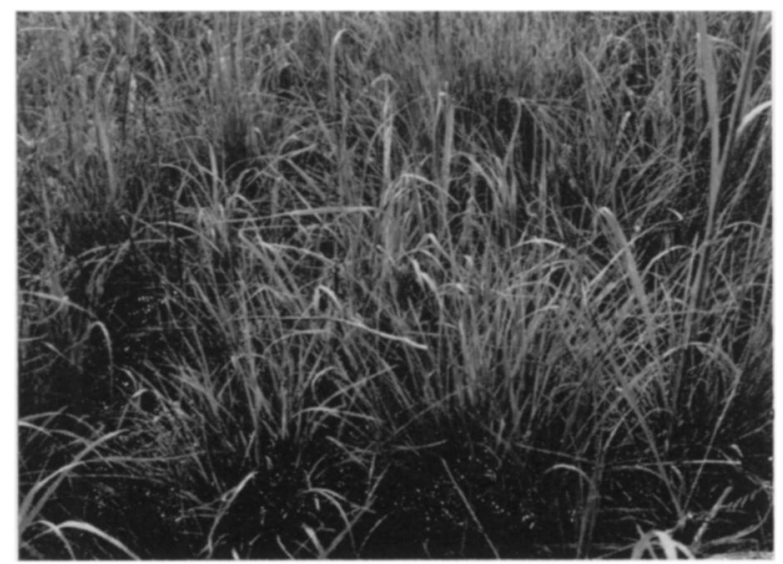

Fig. 10. Recovery of little bluestem in pasture after 2 years of protection. July 25,1938 .

In the north exclosure sand dropseed was the dominant grass everywhere, with side-oats grama second in abundance but of much lower rank and with the plants widely scattered. In many places sand dropseed covered the soil almost completely, the foliage cover being as high as 90 percent late in July when the general grass level was about 12 inches and the flower stalks were 2.5 to 3 feet tall (Fig. 11). At a distance of a few rods, except for the tall daisy fleabane and gumweed, the pasture appeared to be completely dominated: by sand dropseed and a sparse to moderate mixture of side-oats grama. A considerable part of the increase of sand dropseed resulted from the bundant seedlings of the previous summer.

All other grasses were far less abundant, their order of importance being big bluestem, blue grama and hairy grama, little bluestem, June grass, and bluegrass. The considerable amount of big bluestem and somewhat less abundant little bluestem were impressive since in the preceding year they were scarcely to be found. Both species had regained former losses by vegetative propagation, and both pro- 


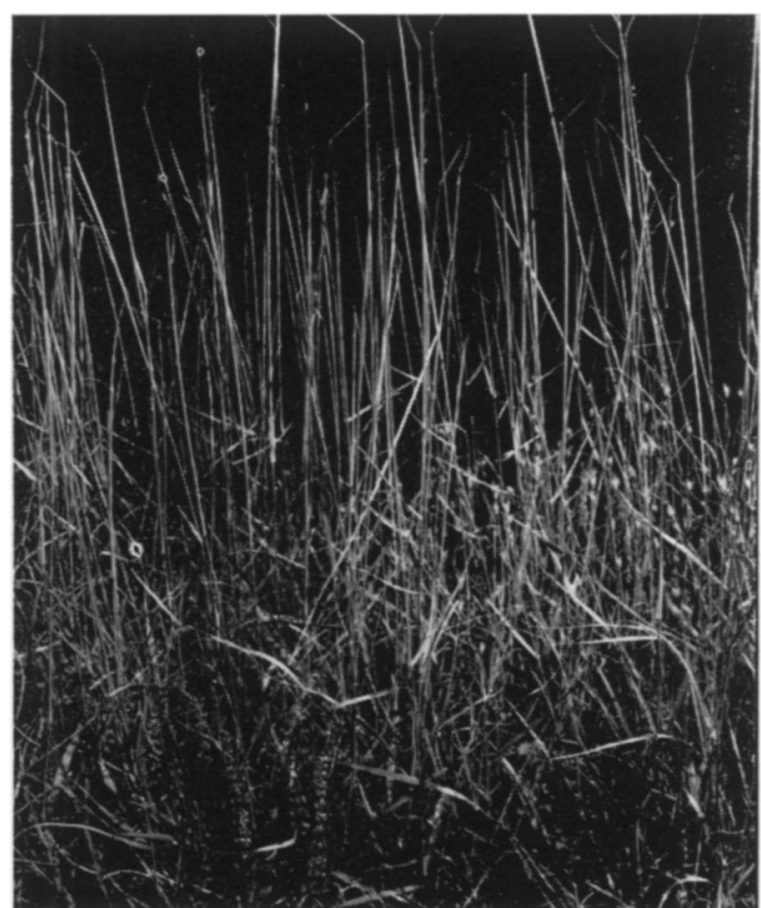

Fig. 11. Dense stand of sand dropseed (Sporobolus cryptandrus) in pasture undergoing a second year of succession. July 25, 1938.

duced seed. Many small bunches of June grass were scattered throughout as were also many new plants of blue grama and tufts of hairy grama. Growth was vigorous in the bared soil. Seribner's panic grass and Wilcox's panic grass were found sparingly throughout and occurred in dense stands about the edges of bare places. Slender eyperus, found only rarely in 1937, was a common and even abundant species in the areas laid bare by the death of bluegrass; patches 5 to 10 square feet in area occurred. Pennsylvania sedge, also profiting by the death of bluegrass, had increased considerably. Bluegrass was represented only by a few small patches and rarely by isolated tufts.

Although prairie grasses were not abundant, considering the area as a whole, yet they did dominate in many scattered square meters, a fact of much importance since it distinctly indicated the beginning of their return.

The two chief weedy forbs in sequence of importance were aster and goldenrod. Aster varied greatly in height and density of stand, depending largely upon competition. In pure stands, often 4 or more feet in length and breadth, it reached a height of 2.5 feet, and the stems from the rhizomes were so densely aggregated that no other plants had returned to the drought-bared areas into which the aster had rapidly spread. The goldenrod attained a height of 2 to 2.5 feet in dense patches where there was practically no grass, but where sand dropseed also occurred the stems were fewer and only 16 inches tall. The larger patches of this rhizomatous species were 12 feet wide and 18 feet long. The plants were often so densely aggregated that even grasses were all but excluded. However, fruiting stalks of sand dropseed and side-oats grama, or less frequently of big bluestem, appeared sparingly from plants enfeebled by the dense shade.

Little barley ranked third in abundance among the weeds, and was followed by Pursh's plantain and rough pennyroyal. These were most abundant in patches of dead bluegrass. They frequently occupied 2 to 8 square feet in pure or mixed stands. In general, the gray spikes of the plantain, the species which dominated small areas the preceding year, were almost completely obscured by the thickening cover of grasses. Indeed, over the lower half of the pasture little barley and rough pennyroyal formed a distinct understory, at a height of 10 to 13 inches, beneath the perennial pasture and prairie grasses. During June, little barley appeared to suppress sand dropseed, but later the cover of this perennial was very thick and the weedy grass was subdued. In the smaller areas where little barley had complete control, the dried stems, 20 inches long, became prostrate and formed dense mats, as occurred over many acres in old worn-out pastures. Except for little barley and plantain, annual weeds were of little significance despite the abundance of horserweed and the scourge of peppergrass in 1937. The perennials -yarrow, vervain, and western ragweed-were present only in moderate numbers. The control of the forbs (except aster and goldenrod) by the general thickening of the grasses was a marked feature in 1938 .

\section{PLANT COVER IN 1940}

By the fourth year of succession sand dropseed still dominated in many places and in mixture with side-oats grama in others. In much of the area it was well intermixed with the bluestems, and frequently the bluestems were dominant and sand dropseed was almost absent. June grass and Pennsylvania sedge were far more common than before, and an occasional bunch of prairie dropseed was encountered. In midsummer, little bluestem stood out conspicuously at a height of 10 inches in reddish bunches and patches. The tops of big bluestem were scorched and the leaves of side-oats grama were rolled. On the lower ground, the dried flower stalks of bluegrass were scattered thinly. Goldenrods were fewer and much dwarfed; they had been thinned greatly as the grasses increased; often only the outlines of former dense patches remained (Fig. 12). The patches of aster were likewise mostly very open, but the plants were taller than in earlier stages of succession (Fig. 13). Yarrow was abundant. Weeds were of minor importance, and the impress was distinctly one of grasses. Vervain, formerly common, had nearly disappeared. The bunches of grass were much thicker, of greater height, and produced many more stems than earlier in the succession.

Patches of blue grama with foliage 6 inches high were common. Occasional bunches of hairy grama, tall dropseed, prairie dropseed, and plains muhly (Muhlenbergia cuspidata) occurred. In autumn, 


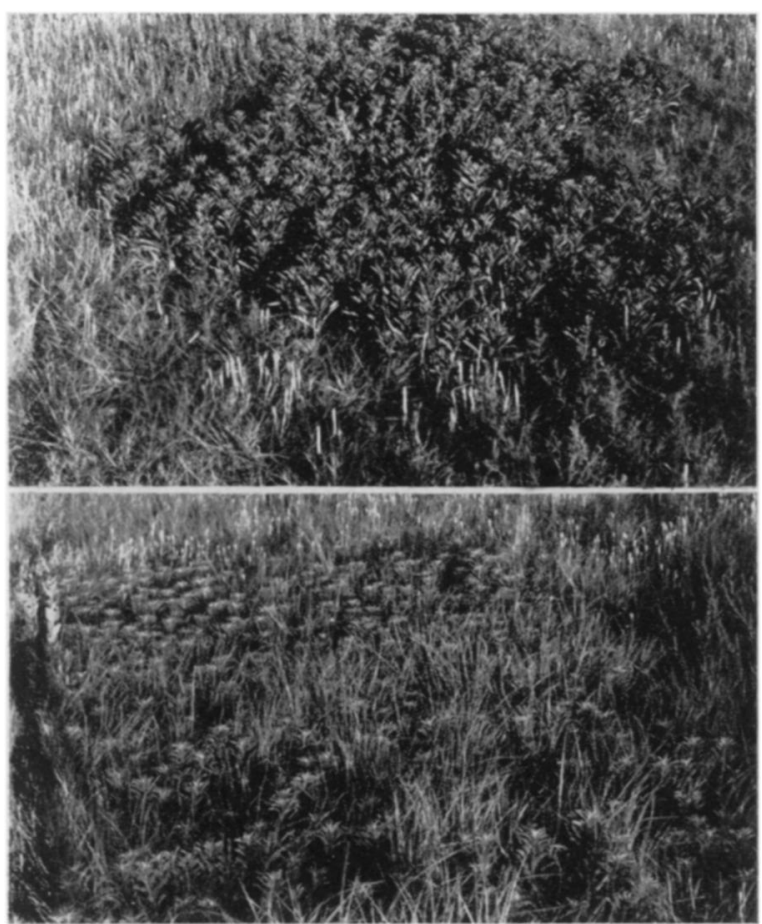

FIG. 12. (Upper) Dense growth of smooth goldenrod (Solidago glaberrima) during the second year of suecession. (Lower) Open growth of smooth goldenrod during the fourth year of succession. It was formerly similar to that above, but is giving way to competing grasses. Complete suppression of this species is shown in Figure $1 \mathfrak{s}$.

where large bunches or patches of the bluestems or of blue grama were present, there was a distinct opening in the general canopy of flower stalks afforded by sand dropseed and side-oats grama. The annual weed stage, especially that of little barley, so conspicuous in the areas with a shorter period of development, had nearly disappeared (Fig. 14). Plantain likewise was inconspicuous. But the development into climax prairie was still far from complete (Fig. 15).

\section{PLANT COVER IN 1944}

Final observations on the course of succession were made in spring and summer of 1944. This was an unusually good year for growth. In May the soil of lower slopes was wet many feet in depth; on upper slopes wet soil occurred to 4 or 5 feet and moist soil to 6 feet. Showers were well distributed and rain often fell in large amounts.

Climax conditions had almost been attained in the south exclosure. Most of it had a 70 percent stand of little bluestem. The ravine was clothed with a dense and continuous cover of big bluestem, tall panic grass, and Indian grass with a few plants of ironweed. Everywhere the foliage cover was thick, usually 80 to 100 percent. The dense cover generally and the absence of weeds were in distinct contrast to conditions during the drought. This vegetation was identical with similar stands in undisturbed prairie.
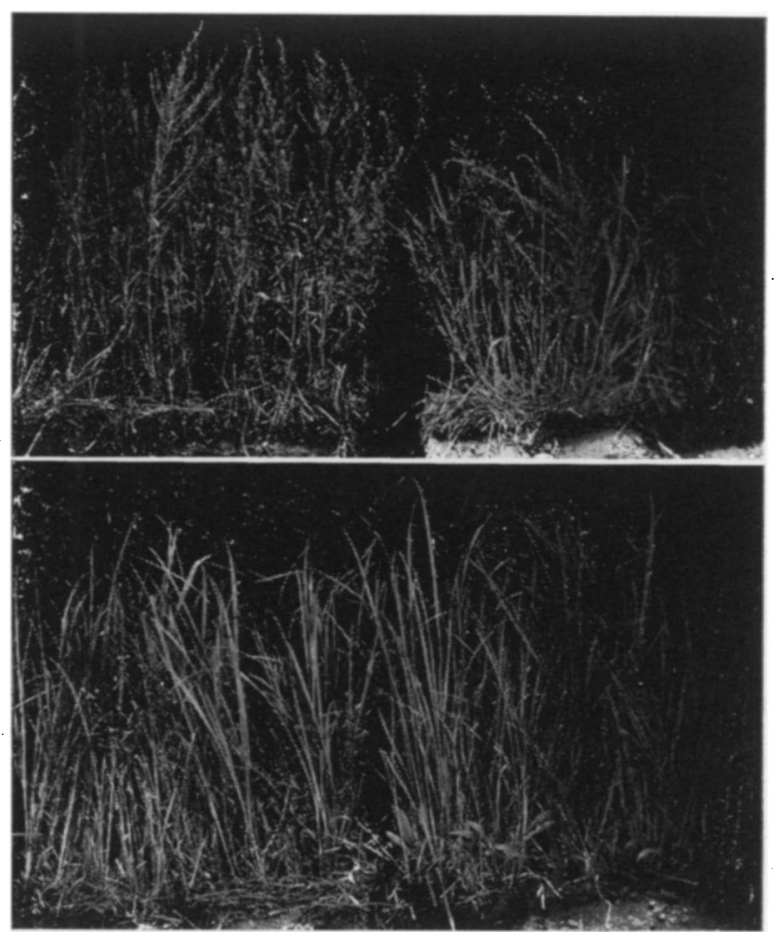

Fig. 13. (Upper left) Dense stand of many-flowered aster (Aster multiflorus) about 2 feet high and with no undergrowth. It was common during the earlier years of succession. (Upper right) Aster growing in a moderately thick stand of sand dropseed. It is shorter and the stems are fewer under competition. (Lower left) Aster greatly suppressed by big bluestem. The height of the grass is about 2 feet and the thick stand casts a dense shade. (Lower right) Representative sod from area shown in Figure 12. The goldenrod is completely suppressed, there are no flower stalks, and the plants with only 2 to 5 percent light are much attenuated. All photos on July 28, 1943.

Only in a single small patch of a few square vards was it revealed that the area had at one time been pasture. Here the cover was sand dropseed, usually thickly intermingled with side-oats grama. But recovery was shown by small bunches of little bluestem and especially by tufts of big bluestem scattered throughout. They were thick on the periphery and foreshadowed a rapid return to a bluestem matrix.

In the larger exclosure, any marked transition from old pasture to climax vegetation along the former fence line had been obliterated. Very little sand dropseed had developed its conspicuous flower. stalks (Fig. 16). Little bluestem, big bluestem, and sideoats grama dominated except where Kentucky bluegrass formed irregular patehes. Bluegrass had begun to replace sand dropseed in 1943 and now occurred thickly on low ground and thinly even on the hilltop. The bunches of bluestem wre erowded with culms, and the bluestem sod was dense. The good foliage height and density of cover with an excellent soil mulch contributed greatly toward making it appear like climax prairie.

Bare so.l was no longer exposed; everywhere be- 


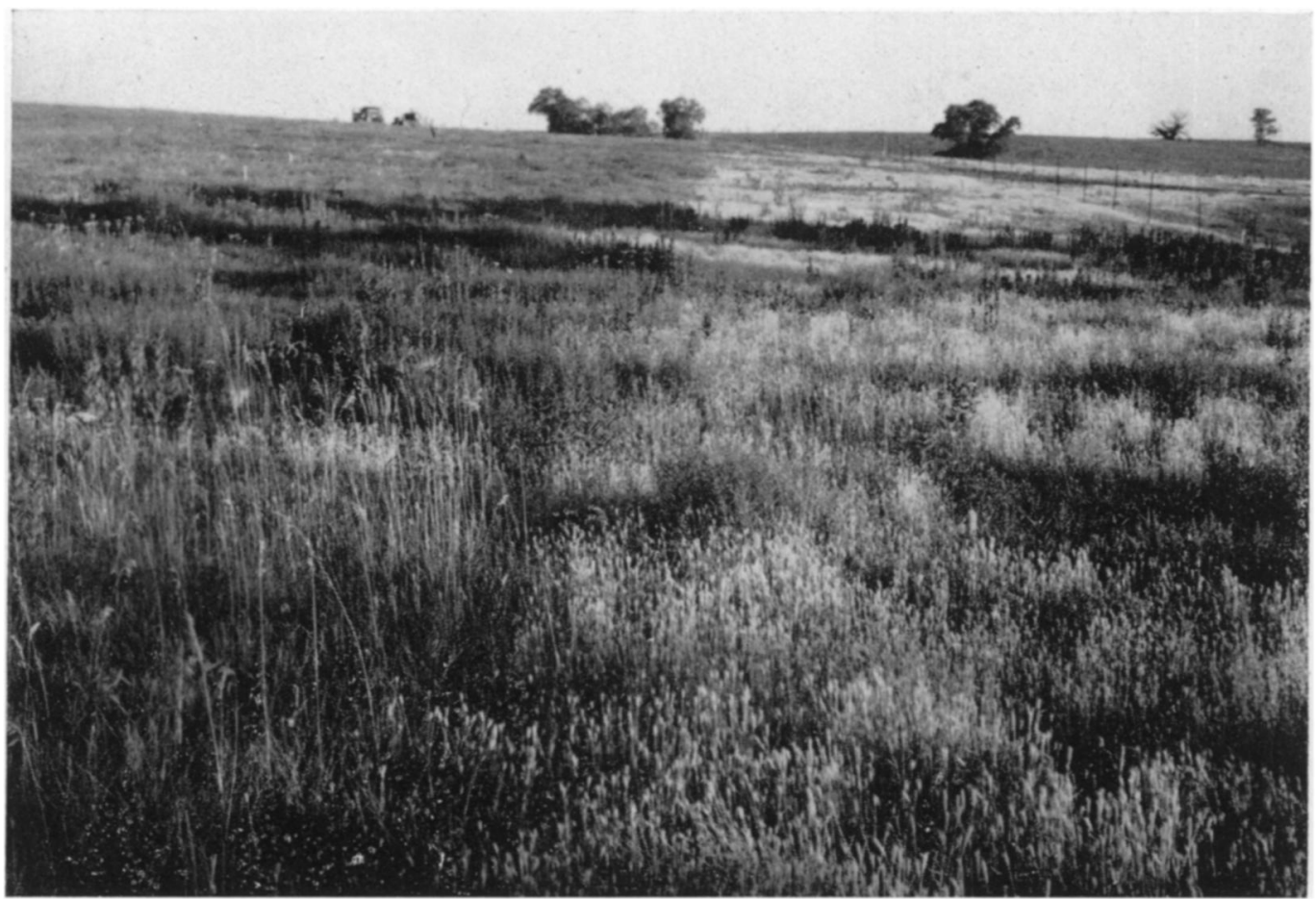

Fig. 14. Vegetation undergoing different periods of succession, June 25, 1940. The former fence line between the fourth year exclosure (left) and the second year exclosure (right) is very distinct because of the abundance of little barley (Hordeum pusillum) which has dried and gives the light color.

tween the plants it was obscured by the mulch of dead and decaying plant parts. Moreover, many species of the understory, as Scribner's panic grass, Wilcox's panic grass, and Pennsylvania sedge, were common. On only a few square yards in places that were formerly destitute of vegetation did sand dropseed still remain, its dense flower stalks reminding one that a few years previously it had prevailed generally. But elsewhere, if present, it was subdued by shade or by a thick mulch of leaves and by root competition as in bluegrass sod. There was only a small amount of hairy chess or other species of brome grass, or of six-weeks fescue and little barley. Pursh's plantain had completely disappeared. All of these are indicators of an open or distrubed cover.

Many-flowered aster, smooth goldenrod, and the perennial ragweed were all greatly subdued and not conspicuous in the deep cover of grass. Practically no pasture weeds remained. The thick bunches of little bluestem had a foliage height of 18 inches. But only the flower stalks of side-oats grama or bluegrass exceeded about a foot in height. Under these grasses shade was dense, and the soil unless clothed with bluegrass was usually without other vegetation. The foliage cover was not so even as that of completely stabilized prairie where more uniform height adjustments had been attained. Sand dropseed lingered longest when intermixed with tufts and small mats of side-oats grama. It thrived best where. light was abundant and its semi-prostrate stems were not too much shaded.

But throughout this intermixture of grasses, the complete recovery and rapid spreading of the bluestems were proceeding everywhere (Fig. 17). Many minor grasses and prairie forbs were also flourishing. Yarrow was generally distributed, and there occurred small amounts of daisy fleabane, false prairie boneset, ground plum, and ironweed. One had only to observe in the adjacent earlier stages of recovery the dense and vigorous patches of, aster to be subdued, the bare spots clothed only with weedy bromes, the abundance of little barley and other annual pasture weeds, and the formidable ranks of the 3-foot flower stalks of sand dropseed, to be reminded of the great changes that had taken place. There the much smaller amount of bluegrass was also striking. Enough dried flower stalks of sand dropseed still remained to clearly demark the boundary line between the areas with the fifth and eighth year of succession.

Conversely, observations in prairie of the abundance of needle grass, the dense stands of prairie dropseed, and the ever-present sprinkling of the lead plant, blazing stars, psoralea, and sunflower, made one realize that stabilization was not yet complete. Nature is conservative; development proceeds slowly especially during times of moisture deficiency, and even subseres for their completion may require a long period of time." Yet the contrast between the new 


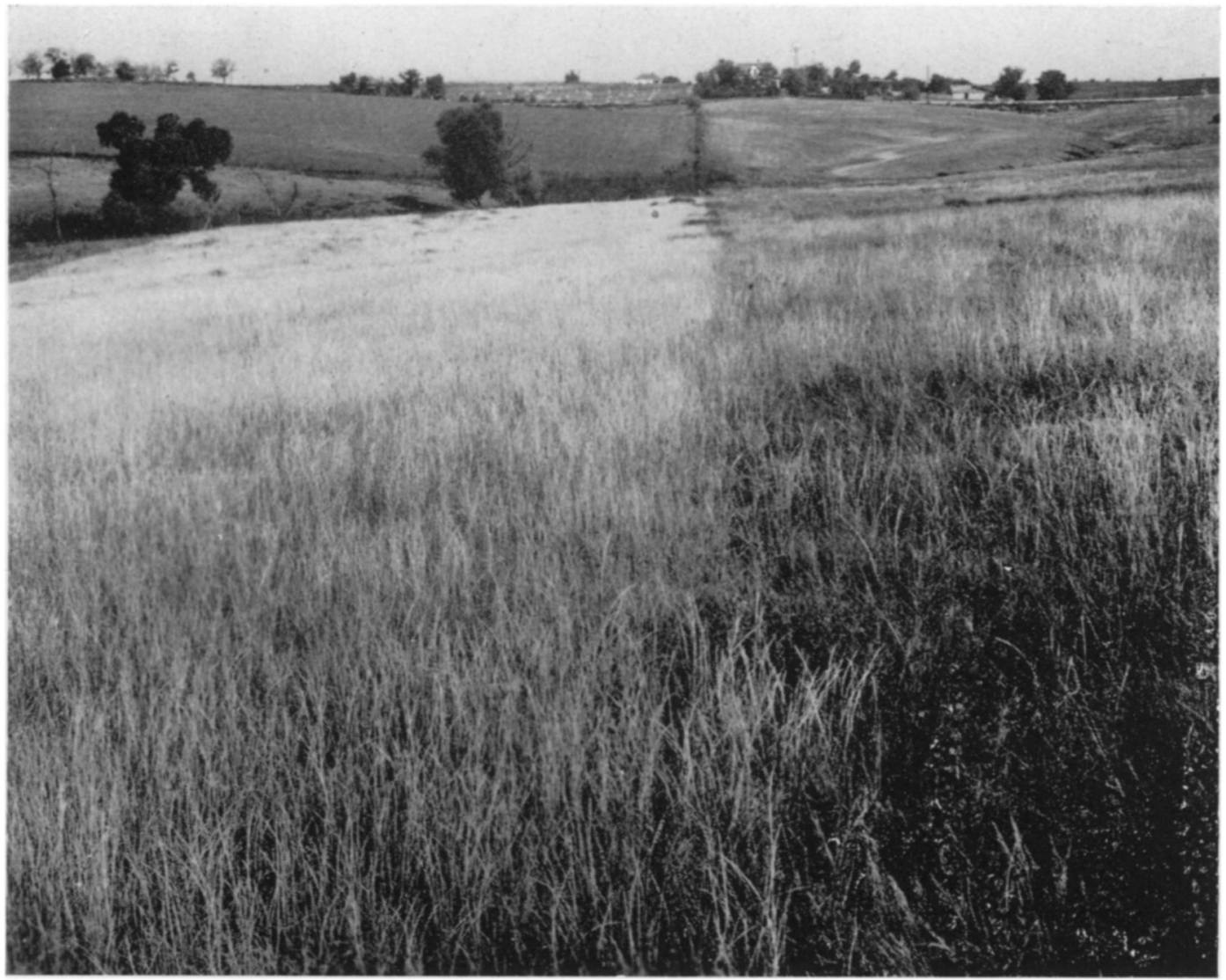

Fig. 15. Photo in September, 1940, showing sharp line of demarcation between elimax prairie (right) and pasture (left). The pasture contains millions of flower stalks of sand dropseed which have bleached white in the late summer drought; they obscure the other vegetation. A little sand dropseed has invaded prairie but here the ehief plant of light color is side-oats grama, which is also abundant in the pasture.

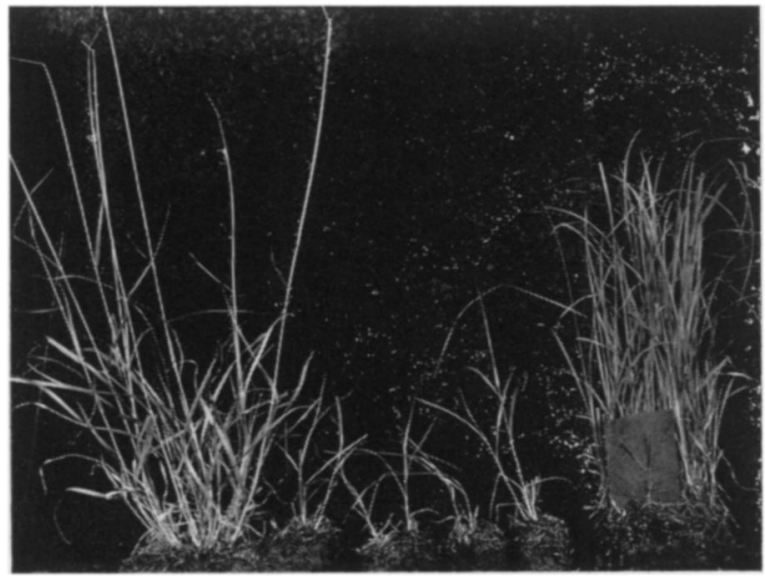

Fig. 16. A typical plant of sand dropseed 2.5 feet tall (left), and different degrees of suppression (center) where the short stems from the large crown were reduced to 1 or 2 in number as a result of shading by big bluestem. (Right) Big bluestem overtopping sand dropseed. The single-stemmed relict in this sod (in front of cardboard) was reduced to a height of only 5 inches. 8-year-old prairie and the depleted ancestral pasture was so great that one could scarcely comprehend their close relationship. Here was the building anew from the old remnants of vegetation, the discarding of weedy invaders, the slow but steady replacement of the former interrelations of native species with species, the delicate readjustment of community relationships which had been all but destroyed. These indeed are phenomena worthy of scientific study, and they are also of far-reaching economic importance.

\section{SUMMARY}

The nature and rate of succession in a 23-year-old native pasture under complete protection from grazing were studied quantitatively near Lincoln, Nebraska, during seven growing seasons, 1937 to 1943.

The pasture was of the little bluestem (Andropogon scoparius)-Kentucky bluegrass (Poa pratensis) type preceding the great drought of 1934-36, but was dominated by sand dropseed (Sporobolus cryptandrus) and side-oats grama (Bouteloua curtipendula) following the high mortality of the less xeric grasses.

Five groups of permanent, meter quadrats were 


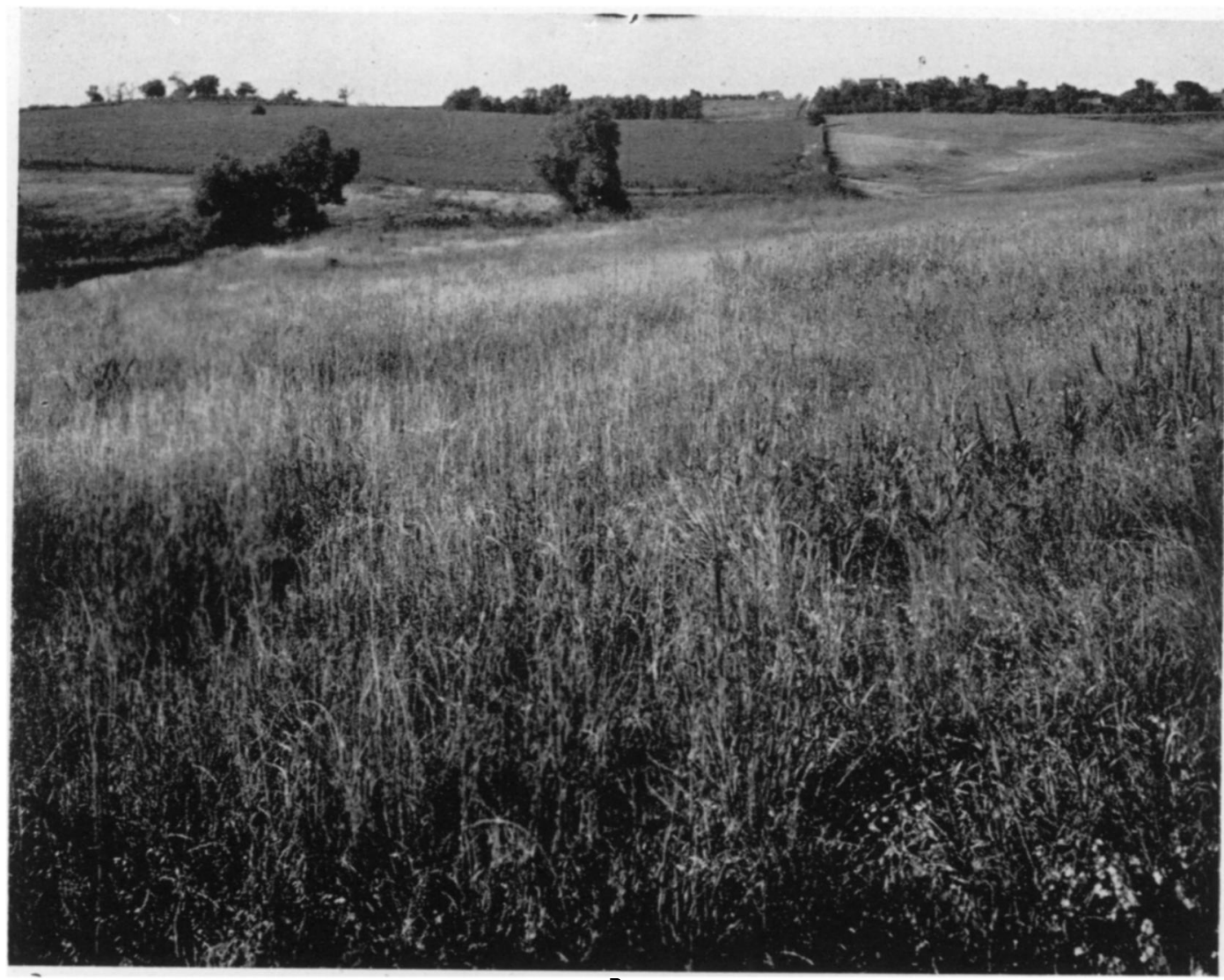

Fig. 17. View on September 24, 1944, showing how the vegetation in the successional area (left) merges imperceptibly into that of the elimax prairie on the right (compare with Figure 15).

established in which the increase or decrease of plants of each species was ascertained by stem-counts.

Fourteen species of grasses and sedges, 19 of native forbs, and 13 ruderals, constituted the total vegetation in the 43 quadrats in 1937 ; the number later increased to 58 .

The topography is rolling; the soil is a fertile clay loam about 3 feet in depth underlaid with a deep, somewhat sandy subsoil. Average annual precipitation is 27 inches.

Drought occurred each growing season until 1942; but conditions for growth were favorable in spring and early summer of 1938 and 1941. Drought was definitely broken in 1942, and excellent growth occurred in 1943 and 1944.

Soil sampling to depths of 6 feet revealed that the vegetation depended chiefly upon current rainfall for its water for growth.

The most marked change in quadrats dominated by sand dropseed was a steady increase (94 percent) in number of stems of the dominant until near the end of the drought. This was followed by a gradual decrease as the more mesic grasses regained their vigor.

In quadrats where little bluestem was most abundant, it gained 332 percent by 1940 and even more during the following good years. Sand dropseed gained steadily even after the severe drought of 1939 40 when nearly all other grasses decreased, but thereafter it lost heavily.

Kentucky bluegrass composed 92 percent of the grass in relict areas quadratted in 1937. It suffered a loss of 99 percent during the following dry fall and winter, and had increased only slightly by 1940 , but very rapidly in 1942-44.

Of the total population of the 43 quadrats bluegrass comprised 56 percent of the perennial grasses in 1937, but only 3 percent in 1938. Sand dropseed, which constituted 26 per cent of the grasses, became more widely distributed than any other species.

Only 5 native forbs were of major importance. Among these Aster multiflorus and Solidago glaberrima both increased greatly, then waned, and later were suppressed.

Foliage cover of vegetation undergoing the first, second, and fourth year of protection was 29, 56, and 61 percent, respectively, in 1940 , but increased to 80 percent or more by 1943 . Basal area was 10, 21, and 20 percent in the same sequence, and no increase occurred after a basal area of about 21 percent was attained in each area.

Diameter of bunches and number and length of stems increased as succession progressed.

Yields under a shorter period of succession were 
often as great or greater than under a longer one, owing to the greater proportion of xeric grasses and weeds the first few years but later to the remarkable growth of prairie grasses freed from too close competition.

In the second year of succession bluegrass maintained only 3 percent of its former stand. Little bluestem had recovered sufficiently to emphasize its relatively small amounts; big bluestem occurred abundantly only in local areas. Invading sand dropseed was usually the dominant grass, with side-oats grama second in abundance. There was much bare soil which the smaller panic grasses, Pennsylvania sedge, and slender cyperus had begun to occupy. Daisy fleabane, aster, and goldenrod were the most characteristic forbs, often occurring in extensive pure patches. Smaller but very abundant were little barley, Pursh's plantain, and rough pennyroyal. They grew thickly in the bare soil.

Near the end of the drought in 1940, sand dropseed still dominated in many places. It still grew in mixture with side-oats grama, but over much area with the bluestems as well. It had been locally replaced by bluestems which had greatly thickened their stands. The bunches and mats of other prairie grasses were also both thicker and more vigorous. Bluegrass had made only slight gains. The patches of goldenrod and aster were somewhat thinned by the grasses, and the plants were dwarfed. The annual weed stage of little barley, Pursh's plantain, and rough pennyroyal had nearly disappeared.

After 8 years, and especially three consecutive good vears, climax conditions had almost been attained. Only in a few places was sand dropseed still abunlant. The bluestems and side-oats grama dominated except in parts of lowlands where bluegrass formed a dense sod. There was no bare soil. All the weedy annuals had disappeared; aster and goldenrod were also absent or greatly subdued. An understory of various minor prairie grasses, bluegrass, and forbs was rapidly developing. Under the dense stand of prairie grasses there was a good mulch of fallen debris. But the absence of certain species of prairie grasses and forbs, common in adjacent climax prairie, and the lack of various community relationships, indicated that succession was still incomplete.

\section{LITERATURE CITED}

Clements, F. E. 1916. Plant Succession. Carnegie Inst. Wash. Pub. 242.

Costello, D. F. 1944. Natural revegetation of abandoned plowed land in the mixed prairie association of northeastern Colorado. Ecology 25: 312-326.

Drew, W. B. 1942. The revegetation of abandoned cropland in the Cedar Creek area, Boone and Callaway counties, Missouri. Mo. Agr. Expt. Sta. Res. Bul. 344.

Sampson, A. W. 1919. Plant succession in relation to range management. U. S. Dept. Agr. Bul. 791.

Weaver, J. E. 1943. Replacement of true prairie by mixed prairie in eastern Nebraska and Kansas. Ecology 24 : 421-434.

1944. Recovery of midwestern prairies from drought. Amer. Phil. Soc. Proc. 88 : 125-131.

Weaver, J. E., \& F. W. Albertson. 1936. Effects of the great drought on the prairies of Iowa, Nebraska, and Kansas. Ecology 17: 567-639.

Weaver, J. E., \& F. W. Albertson. 1939. Major ehanges in grassland as a result of continued drought. Bot. Gaz. 100: 576-591.

Weaver, J. E., \& F. W. Albertson. 1944. Nature and degree of recovery of grassland from the great drought of 1933 to 1940. Ecol. Monog. 14: 393-479.

Weaver, J. E., \& W. W. Hansen. 1939. Increase of Sporobolus eryptandrus in pastures of eastern Nebraska. Ecology 20: 374-381.

Weaver, J. E., \& W. W. Hansen. 1941. Native midwestern pastures; their origin, composition, and degeneration. Univ. Nebr. Cons. \& Surv. Div. Bul. 22.

Weaver, J. E., \& W. W. Hansen. 1941a. Regeneration of native midwestern pastures under protection. Univ. Nebr. Cons. \& Surv. Div. Bul. 23'.

Weaver, J. E., \& V. H. Hougen. 1939. Effect of frequent elipping on plant production in prairie and pasture. Amer. Midland Nat. 21: 396-414.

Weaver, J. E., \& I. M. Mueller. 1942. Role of seedlings in recovery of midwestern ranges from drought. Ecology 23 : 275-294. 